\title{
サクション基礎を利用した防波堤の波浪応答に関する 実験および解析
}

\author{
山㠃浩之 $^{1} \cdot$ 下迫健一郎 ${ }^{2} \cdot$ 中川将秀 ${ }^{3}$ \\ ${ }^{1}$ 正会員 工修 港湾空港技術研究所 地盤・構造部（T239-0826 神奈川県横須賀市長瀬 3-1-1） \\ ${ }^{2}$ 正会員 港湾空港技術研究所 海洋・水工部（同上） \\ ${ }^{3}$ 正会員 工修 東洋建設株式会社 総合技術研究所美浦研究所（广300-0424 茨城県稲敷郡美浦村受領 1033-1）
}

\begin{abstract}
本文は，サクション基礎を防波堤基礎として利用した場合の波浪作用時のサクション基礎地盤の応答を主に 間隙水圧，土圧（鉛直応力）について調べたものである．検討は，大規模波動地盤総合水路を用いた水理模型 実験および地盤を弾性体と仮定した有限要素解析により行った，その結果，波浪作用時にはサクション基礎部 に負の間隙水圧が発生し，波力に対する抵抗に奇与していることが確認された．また，水平荷重に対する負の 間隙水圧の発生機構も明らかにした.
\end{abstract}

Key Words: suction foundation, breakwater, ocean wave, response, negative pore water pressure

\section{1. はじめに}

サクション基礎 ${ }^{1)}$,2) は, 根入れを有する基礎で, 基礎 の根入れは, 図-1に示すように下面がオープンの函を海 底面に据付け，その後函内の海水を吸出して函の内外に 水頭差を生じさせ，これを押込み力として行われる。 こ の際，函内では間隙水圧が静水圧以下となり，静水圧か らの差をサクションと定義し，このことから同基礎はサ クション基礎と呼ばれている. また, 函内外の水頭差は 海底地盤中に上向きの浸透圧を生じさせるので有効応力 の低下により地盤の強度が低下し根入れが容易となる。 根入れ後は, サクションは開放されサクション基礎は根 入れ鋼板セルなどの根入れを有する基礎と同じような機 能を持つ基礎となる.

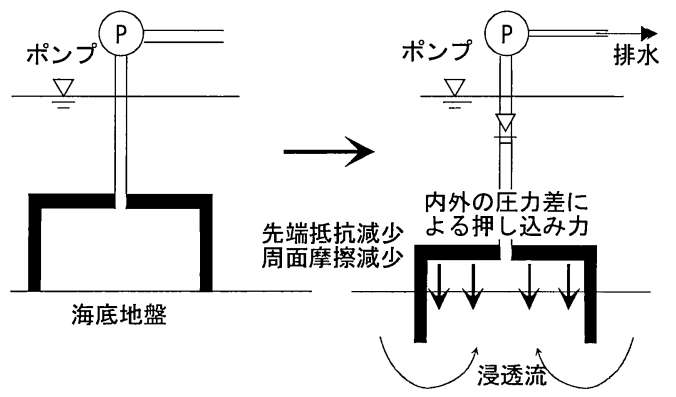

図-1 サクション基礎の沈設
サクション基礎の防波堤基礎としての利用は既に行 われており ${ }^{3)}$, 4), その根入れ後の安定性に関する長所は, (1)根入れがあるので水平荷重に対しては根入れ前面の受 働抵抗が期待できることと，(2)外力が作用する場合には 根入れ部で負の間隙水圧が発生し抵抗が大きくなること である.

ここで，(1)の受働抵抗については既に模型実験等で確 認, 検討され ${ }^{5), 6)}$, サクション基礎を防波堤として利用 した場合の設計法に取り入れられている7，8). しかしな がら, (2)の外力に対して発生する負の間隙水圧について は，図-2に示すように，外力を上向きに作用させた場合 には, 負の間隙水圧が発生することは実験で確認されて いる ${ }^{9)}$ が, 波力のように水平力が構造物に作用した場合 ではどのように負の間隙水圧が発生するか不明なところ が多い。このようなことから，(2)の負の間隙水圧につい ては安全側を考慮して設計には取り入れられていない。

著者らは水理模型実験で防波堤基礎の場合の負の間 隙水圧の発生を調べており, 堤体前面の地中部（基礎前 面主働土圧側）では図-2 の右側のように押し波時に水平 力が作用した場合に反作用的に負圧が生じていることを 間隙水圧の挙動から既に報告している ${ }^{10)}$ 。ここでは, 基 礎内部，基礎底面での負の間隙水圧の発生を確認するこ とを目的に土圧，間隙水圧，基礎変位の挙動を検討し， さらに, 地盤を弾性と仮定した有限要素法による数值解 析で模型実験結果の解析を行った. 


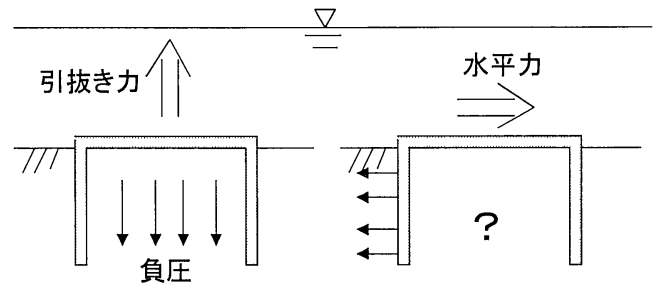

図-2 外力に対する負の閒隙水圧の発生

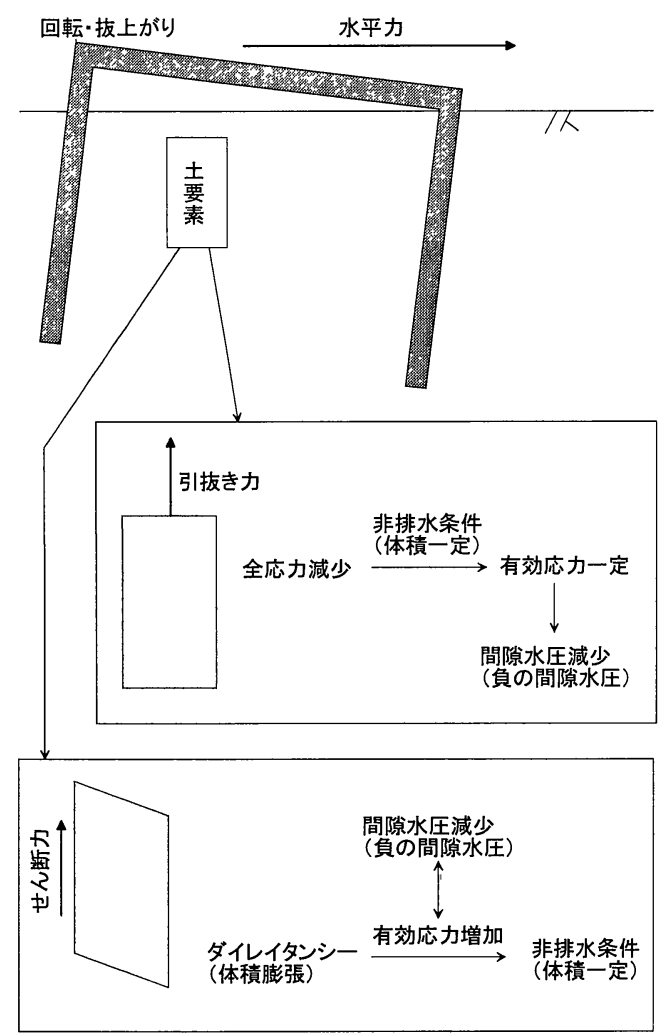

図-3 水平力に対する負の間隙水圧の発生機構

\section{2. 負の間隙水圧の発生機構}

波浪のような水平力が作用した場合には, 図-3に示す ように $2 つ の$ 機構に基づいた負の間隙水圧が発生すると 考えられる. 一つは基礎内部の土要素に作用する全応力 の変化に基づくもので，水平力作用時に基礎下端が支点 となり回転により反対側が浮き上がりの挙動を示し, 引 き抜き力により土要素に作用している全応力は低下する と考えられる. そして, 基礎内部では非排水条件が保た れるので体積は一定で，そのためには有効応力は一定と ならねばならず間隙水圧は減少する。 これが負の間隙水 圧の発生となる，もう一つは基礎内部の土要素にせん断
カが作用し，これにより発生するダイレイタンシー（体 積膨張）に基づくものである. すなわち，基礎内部では 非排水条件が保たれており土要素の体積は一定でなけれ ばならないので，せん断に伴う体積膨張を打ち消すため には有効応力が増加しなければならず，そのために間隙 水圧は減少する. これが負の間隙水圧となる. 以上のう ち, 前者は非排水条件下での外力の作用に対して発生す る反作用的なもので，土を弾性体と取り扱っても説明で きる. 後者は土のダイレイタンシーに基づいて発生する ので, ダイレイタンシー特性が考慮されていなければ説 明できない，また，必ずしも引き抜き状態である必要は なく，押込み状態でも発生しうるものである. ただし， 一般に正のダイレイタンシーは非常に緩詰め状態の砂や 正規圧密粘土では発生しないので，正のダイレイタンシ 一による負の間隙水圧発生は土の状態に依存する.

以上のように仮定した負の間隙水圧の発生機構を念 頭に, 以降では波力作用時の負の間隙水圧の発生につい て実験と数值計算により検討を進める.

\section{3. 水理模型実験}

サクション基礎を利用した防波堤の波浪作用時の基 礎部の応答特性を調べるために, 大規模波動地盤総合水 路を用いた水理模型実験を行った ${ }^{10), 11)}$.

\section{(1) 模型実験概要}

\section{a) 実験水路と堤体断面}

実験水路 ${ }^{12)}$ は, 図-4に示すように, 長さ $184 \mathrm{~m}$, 幅 $3.5 \mathrm{~m}$, 深さ $12 \mathrm{~m}$ で, 中央部に長さ $67 \mathrm{~m}$, 樑さ $4 \mathrm{~m}$ の砂地盤槽を 有している. 砂地般にはオーストラリア産フラタリーサ ンドが用いられており, 物理特性は $50 \%$ 通過粒径が $D_{50}=0.2 \mathrm{~mm}$, 最大密度 $\rho_{\mathrm{dmax}}=1.676 \mathrm{~g} / \mathrm{cm}^{3}$, 最小密度 $\rho_{\mathrm{dmin}}=1.407 \mathrm{~g} / \mathrm{cm}^{3}$, 土粒子密度 $\rho_{\mathrm{s}}=2.651 \mathrm{gcm}^{3}$, 均等係数 $U_{\mathrm{c}}=1.5$ で, 透水係数が $k=0.05 \mathrm{~cm} / \mathrm{s}$ のきれいな砂である. 地盤層は地盤槽下部に設けられた液状化注水装置により 上向きに大きな浸透流を作用させ緩詰め状態にすること ができる.また，緩詰め状態の地盤上に波浪を作用させ ることにより地盤の高密度化が可能である.

堤体は, 図-5に示すように砂地盤槽に設けられており, 計測用堤体とその両脇のダミ一堤体の 3 函からなってい る. 計測用堤体は円筒状のサクション基礎部と矩形のケ ーソン部からなっており, サクション基礎部（鋼材+コ ンクリート製）は外径 $2.0 \mathrm{~m}$, 肉厚 $5 \mathrm{~cm}$, 高さ $0.9 \mathrm{~m}$ の円 筒で, ケーソン部（鋼材）は幅 $1.0 \mathrm{~m}$, 高さ $1.8 \mathrm{~m}$, 奥行 き $2.1 \mathrm{~m}$ の矩形で, 水中重量は $0.7 t$ である. 表- 1 には使 用したセンサーの容量を示す. 
$184 \mathrm{~m}$

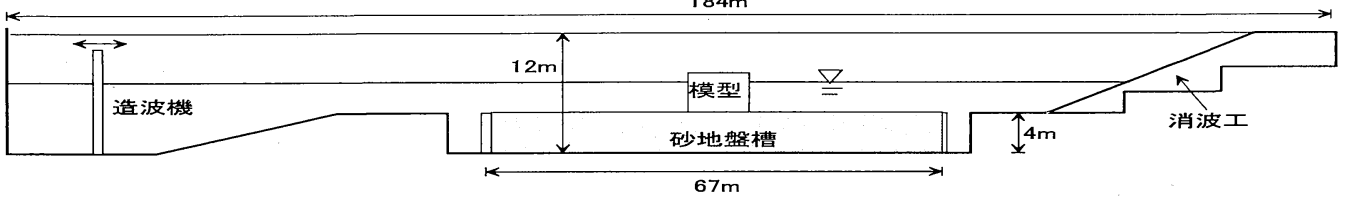

図-4 実験水路
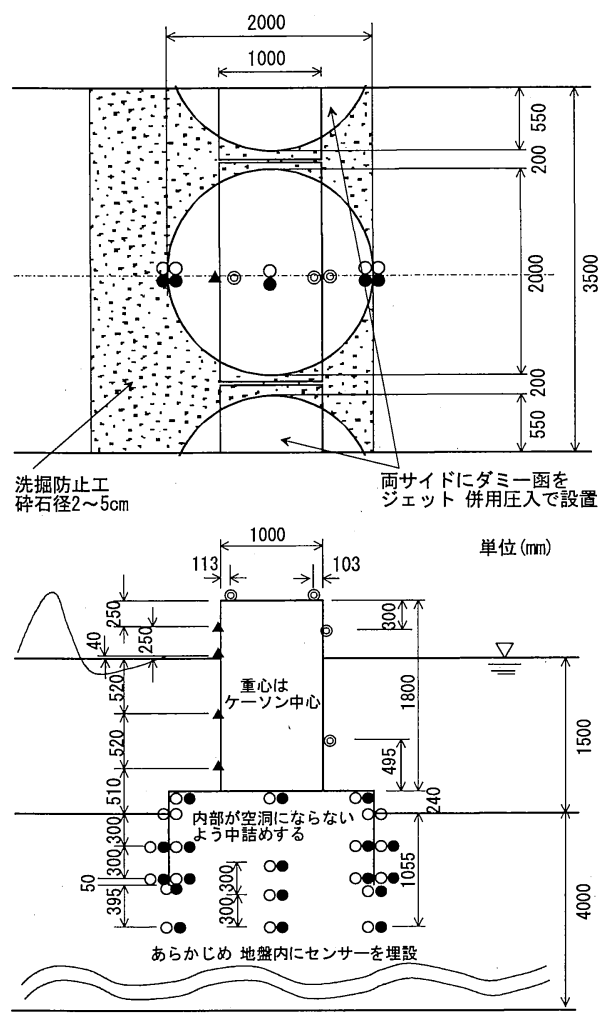

図-5 (a) 実験模型

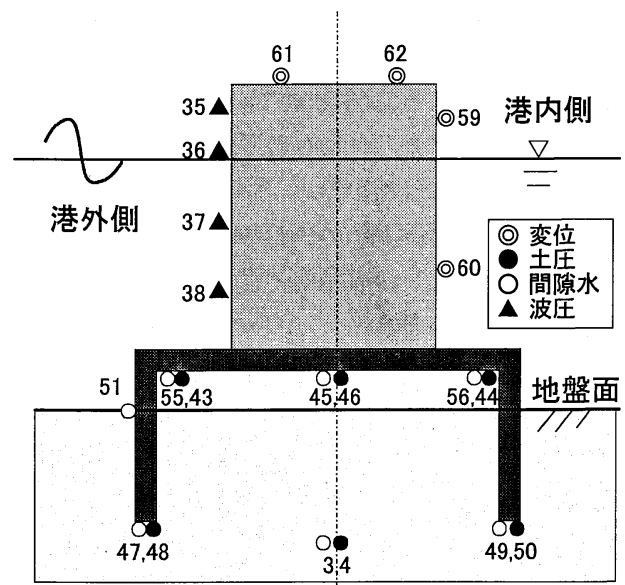

図-5(b) 検討対象としたセンサー
表-1 模型実験で用いたセンサー

\begin{tabular}{|c|c|c|c|}
\hline \multirow{3}{*}{$\begin{array}{l}\text { 測足固听 } \\
\text { 基礎隅角部 } \\
\text { 基礎中央上端 }\end{array}$} & センサー & \multicolumn{2}{|c|}{ |図-5(b)での番号容量 } \\
\hline & 土圧計 & $44,43,46$ & $100 \mathrm{kN} / \mathrm{m}^{2}$ \\
\hline & 間隙水圧計 & $45,55,56$ & $50 \mathrm{kN} / \mathrm{m}^{2}$ \\
\hline 下端 & 土圧計 & 4 & $200 \mathrm{kN} / \mathrm{m}^{2}$ \\
\hline 基砝 & 間嚐水圧計 & 3 & $200 \mathrm{kN} / \mathrm{m}^{2}$ \\
\hline 港外側基礎下端 & 土圧計 & 48,50 & $500 \mathrm{kN} / \mathrm{m}^{2}$ \\
\hline 港内側基礎下端 & 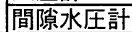 & 47,49 & $50 \mathrm{kN} / \mathrm{m}^{2}$ \\
\hline 港外側基礎側面 & 間箁水圧計 & 51 & $50 \mathrm{kN} / \mathrm{m}^{2}$ \\
\hline ケーソン港外側側面 & 司波圧計 & $35,36,37,38$ & $50 \mathrm{kN} / \mathrm{m}^{2}$ \\
\hline \begin{tabular}{|l|} 
ケーソン天端 \\
ケーソン港内側側面
\end{tabular} & 変位計 & $59,60,61,62$ & 15 \\
\hline
\end{tabular}

\section{b) 実験方法}

堤体設置前の地盤密度は，直接計測したものではない が, 簡易動的コーン貫入試験の $\mathrm{N}_{\mathrm{d}}$ 值から推定したところ, 乾燥密度は $\rho_{\mathrm{d}}=1.55 \mathrm{~g} / \mathrm{cm}^{3}$ （水中単位体積重量は $\gamma$ ' $\left.=9.5 \mathrm{kN} / \mathrm{m}^{3}\right)$ で, 相対密度は $D_{\mathrm{r}}=60 \%$ 程度であった. なお, 利用したフラタリーサンドの簡易動的コーン貫入試験と 乾燥密度の関係は, 別途小型土槽でキャリブレーション を行って求めておいたものであるが， $\rho_{\mathrm{d}}=1.55 \mathrm{~g} / \mathrm{cm}^{3}$ に対 応する $\mathrm{N}_{\mathrm{d}}$ 值は 1 2 程度で, $\mathrm{N}_{\mathrm{d}}$ 值から推定できる密度の 下限值に相当している．また，乾燥密度を簡易動的コー ン貫入試験から間接的に求めたのは，地盤から乱さない 試料をサンプリングするのが困難であったことによる.

フラタリーサンドの三軸試験結果によると相対密度 が $D_{\mathrm{r}}=60 \%$ 程度の供試体のせん断抵抗角は $\phi^{\prime} \fallingdotseq 35^{\circ}$ で ある.

計測用堤体の設置では，サクション基礎部の円筒は, 実際の沈設と同じように，サクションをかけながら地盤 内に沈設させた. 沈設の際にはサクション負荷によりボ イリングなどの地盤の乱れが生じないように, サクショ ンを調整しながら行った. 沈設後, 基礎上版 (上蓋) を はずして基礎内の地盤面を測定したところ，沈設時の基 礎内への地盤の盛上がり量は $6 \mathrm{~cm}$ 程度で, これはサクシ ヨン基礎側壁部の地盤への貫入に伴う排土量とほぼ同じ 量である. したがって，地盤が膨張するなど，沈設時の サクション負荷による地盤への影響は少なかったといえ る. 両脇のダミ一函は水ジェットを用いて沈設した。 サ クション基礎沈設は, 図-5(a)に示したように地盤深さ約 $65 \mathrm{~cm}$ まで行っており, 地盤面より上部に $24 \mathrm{~cm}$ 基礎内に 空洞ができている．沈設後，地盤面より上部の基礎内を 砂で中詰めした．その後，ケーソンを据付け基礎頂盤に 固定した. なお，上部ケーソンは下部のサクション基礎 
と剛結されているので，ケーソンはサクション基礎と一 体で挙動する.

計測は，図-5(a)で示した䇢所で，波圧( $\boldsymbol{\Delta} ， 4$ 箇所),

間隙水圧 $(\bigcirc, 22$ 箇所), 土圧 $(\boldsymbol{O}, 18$ 籄所), 変位(@，4 箇所)の各項目について行ったが，本論文では，図-5(b) に示す主要な箇所の計測項目について検討する.

表-2 模型実験の波浪条件

\begin{tabular}{|c|c|c|c|c|}
\hline \multirow{6}{*}{$\begin{array}{l}\text { 波 } \\
\text { 浪 } \\
\text { 条 } \\
\text { 件 }\end{array}$} & 水深(m) & 周期(s) & 波高(cm) & $\begin{array}{c}\text { ケース } \\
\text { 名 }\end{array}$ \\
\hline & \multirow{5}{*}{1.5} & \multirow{5}{*}{2.5} & 20.0 & CaseA1 \\
\hline & & & 30.0 & Case $\mathrm{A} 2$ \\
\hline & & & 40.0 & CaseA3 \\
\hline & & & 50.0 & CaseA4 \\
\hline & & & 58.9 & CaseA5 \\
\hline
\end{tabular}

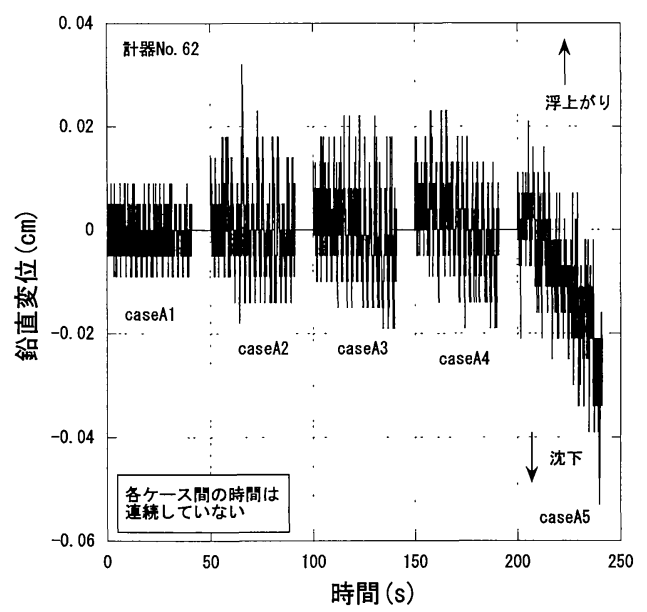

図-6＼cjkstart各ケースの鉛直変位の時刻歴

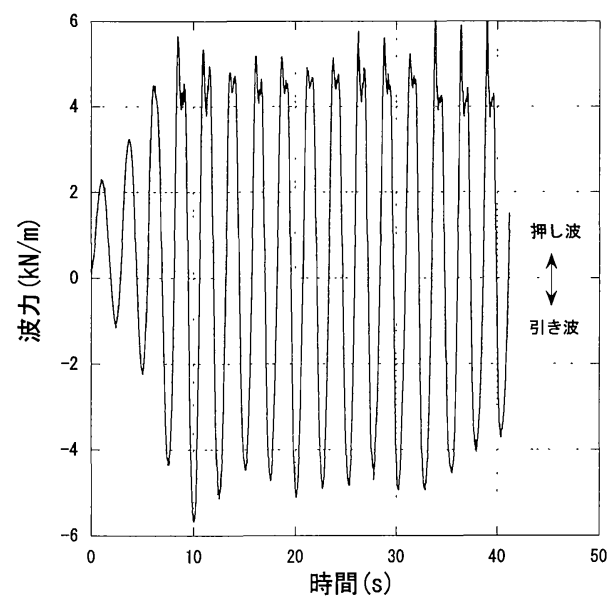

図-7 波力と時間の関係
実験は表-2 に示すように, 水媣 $1.5 \mathrm{~m}$ で, 波浪周期 $2.5 \mathrm{~s}$ の規則波により波高を変えて CaseA1〜A5 の 5 ケース行 った. 各ケースの波浪の載荷回数は 16 波である. また, 波浪載荷は CaseA1 から CaseA5 まで連続的に行った. た だし，各ケース間には載荷させた波浪が静穏になるまで の時間を設けている. 模型堤体は, 現在提案されている サクション基礎構造物の設計法 ${ }^{13)}$ によると, CaseA5 の 波高 $58.9 \mathrm{~cm}$ で破壊する設計になっている.

以上のように実験を行ったが，ここでは，最も大きな 波高を載荷させたCaseA5 を取り上げて検討する.なお, 図-6に, CaseA1〜A5 までの全ケースについて, 計器 No.62 で計測した鉛直変位（沈下が負）の時刻歷を参考 と、して示寸が, CaseA1〜A4 では残留変位はほとんど生 じず, CaseA5 においては破壊しなかった. CaseA5 では 破壊する設計になっていたが，破壊しなかった理由の一 つとして波浪作用時に設計で考慮されていない負の間隙 水圧が基礎内に発生し抵抗に寄与したことが考えられる.

\section{(2) ケース A5 の計測値の時刻歴と堤体挙動の概要}

\section{a) 波力}

図-7 に CaseA5 での水路幅方向の単位幅あたりの波力 の時刻歴を示す. 単位幅あたりの波力は図-5(b) の No.35 〜38 の波圧計と No.51の間隙水圧計で計測された圧力分 布から算出したものである. 図-7 から, 波力振幅は最初 の 4 波( 0 〜 $10 \mathrm{~s})$ では徐々に大きくなり, 4 波以降(10s 以降) ではほぼ土 $5 \mathrm{kN} / \mathrm{m}$ の值で定常的になっていることがわか る.

b) 変位

図-8に CaseA5 の水平变位, 鉛直変位, 傾斜角の時刻 歴を示寸. 水平変位と鉛直変位の計測位置は図-5(b)の No.59 と No.62 の変位計で計測されたもので, 傾斜角は No. 59 と No.60 の変位計から算出したものである. 傾斜 角の符号は港内側への傾斜が正である.

図-8(a)から，水平振幅は徐々に大きくなり，4波以降 では定常的となっている.これは, 図-7の波力に対応し た結果となっている. 定常状態での振幅は, 港内側で 0.15 $\sim 0.2 \mathrm{~cm}$, 港外側で約 $-0.1 \mathrm{~cm}$ の変位となっており港内側 に大きめの值となっている.

図-8(b) から，鉛直変位は波浪載荷に伴い徐々に負の 値に蓄積されており, 模型堤体は沈下していることがわ かる. 変位の振幅を水平変位の振幅と比較すると, 1 オ ーダー小さい.

図-8 (c) から, 傾斜角は水平振幅と同じく徐々に大き くなり, 4 波以降では定常的となっている. 4 波以降の傾 斜角の振幅は正の方向では約 $0.06^{\circ}$, 負の方向では約 $-0.03^{\circ}$ で港内側に大きくなっている. サクション基礎周 囲の地盤が単純せん断変形をしていると仮定し, 傾斜角 がせん断ひずみに対応すると考えると，地盤に発生した 


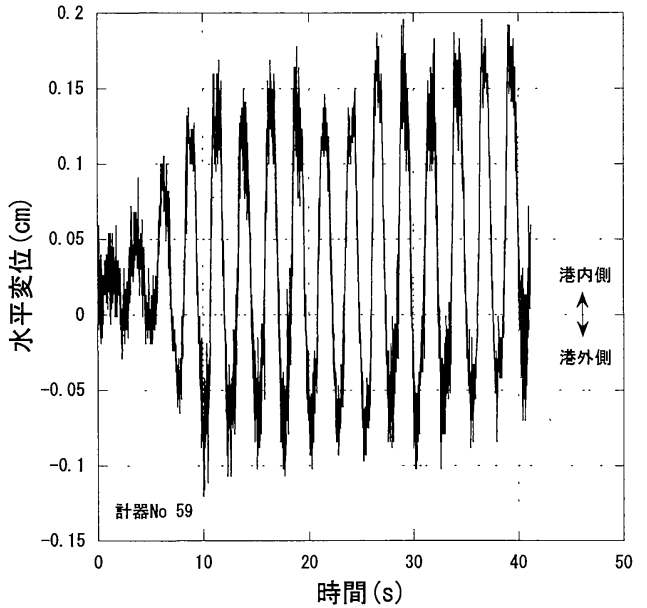

図-8（a）水平変位の時刻歴

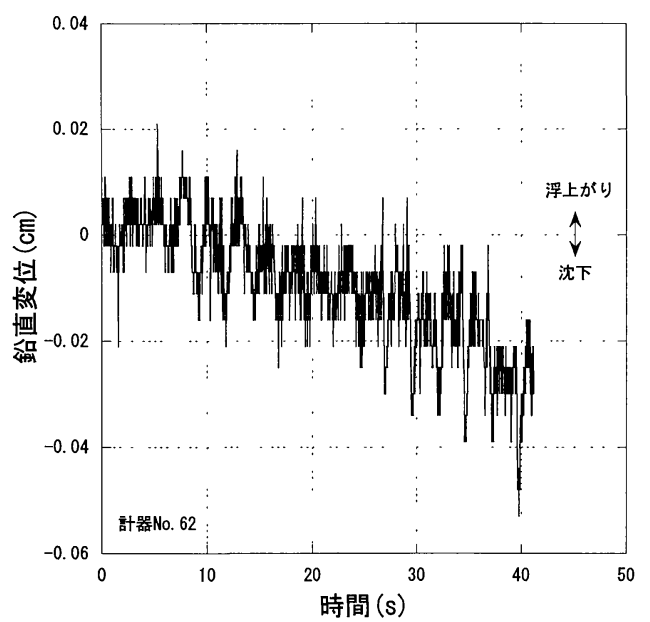

図-8(b) 鉛直変位の時刻歴

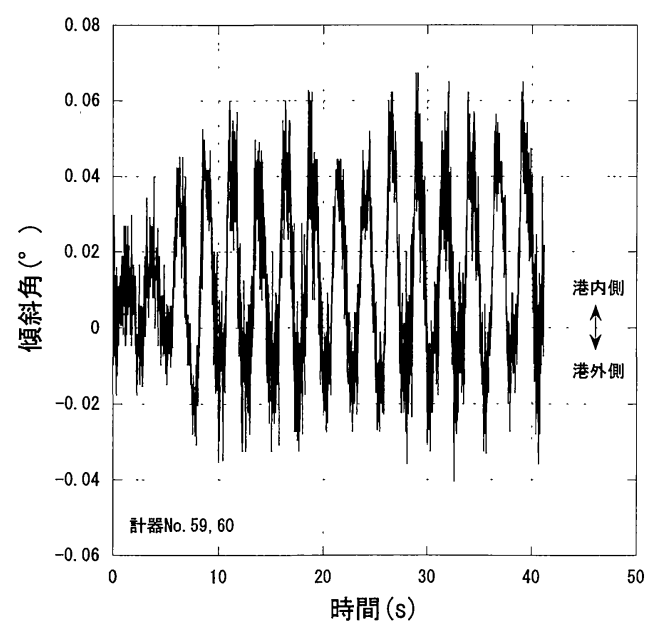

図-8(c) 傾斜角の時刻歴

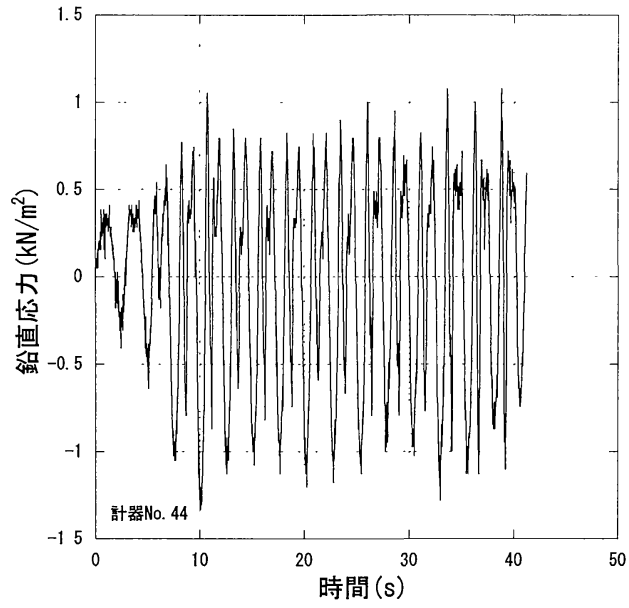

図-9（a） 鉛直応力の時刻歷

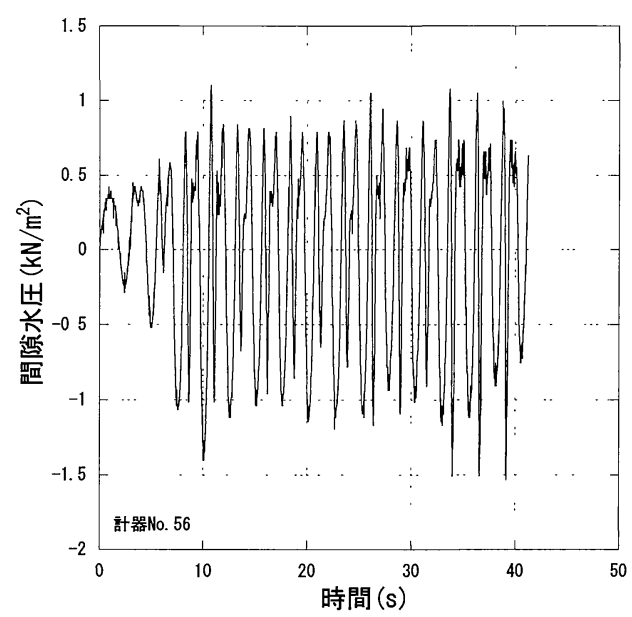

図-9(b) 間隙水圧の時刻歴

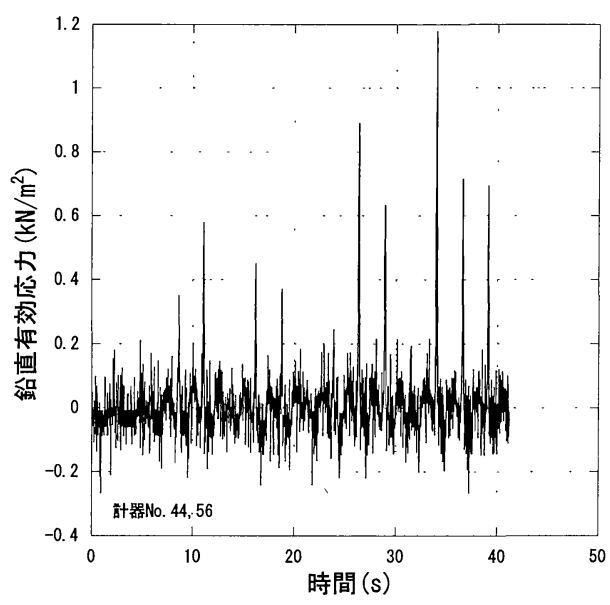

図-9(c) 鉛直有効応力の時刻歴 
ひずみはおおよそ $10^{-3}$ 程度のひずみに相当することにな る.ここで，傾斜角の振幅を $0.05^{\circ}$ として回転中心を基 礎下端とすると，これによる水平変位(図-8 (a) の変位の 計測地点 No.59)は約 $0.2 \mathrm{~cm}$ になり, 今回の実験では堤体 の水平変位のほとんどは回転成分によるものとなる.

c) 鉛直応力, 間隙水圧, 有効応力

鉛直応力(土圧), 間隙水圧の時刻歴の一例として, 図 -5 の No.44(土圧計)と No.56(間隙水圧計)の計測值を図 -9 (a)，（b）に示す．鈆直応力と間隙水圧の值は波浪載荷 前の值を除いたもので，波浪載荷中に発生した動的な成 分と残留成分の和である. 図-9 (c) には図-9(a)，(b)の鉛 直応力と間隙水圧から求めた有効鉛直応力の時刻歴を示 す.

図-9 (a)，(b) から最初の 4 波にかけ鉛直応力と間隙 水圧の振幅は大きくなっており，4 波以降は定常的にな っているといえる. この傾向はa)とb)で示した波力, 変 位の傾向と同じである.

図-9(c) から, 波浪載荷とともに鉛直有効応力が減少 していく傾向はない. したがって, 載荷による過剩間隙 水圧の蓄積は大きくはなく, 水圧の応答については残留 成分が大きく蓄積されない応答であったといえる.また, スパイク状に大きな鉛直有効応力が発生しているところ がある.これは 2. 負の間隙水圧の発生機構で述べたせ ん断によるダイレイタンシーに起因した負の間隙水圧の 発生と関連している可能性があり，後述の図-12(e), 13, 21 において考察を加える.

以上の a)〜c)の設計波相当を作用させたケース A5 は， 大きな残留変位は生じないが，繰返し載荷によるいわゆ るゆり込み沈下が生じる程度の波浪条件であったことが わかる.変形モードは回転成分が卓越していたといえる. また，地盤内の応力の時刻歷は波浪が定常的になる 5 波 以降では定常的である. これらのことから，以降の波力 に対する堤体，基礎の応答については， 5 波目の波浪載 荷時に着目して説明する.

\section{（3）波力に対する堤体，基礎の応答と負の間隙水圧発生}

CaseA5 の波力と堤体，基礎の応答に関して載荷時間 10.6 13.1s の波力之堤体変位, 基礎の土圧, 間隙水圧の 関係を調べる. 図-10 には参考として波力と No.37 で計 測した波圧の関係を示寸. 波力は No.35〜38 と No.51の 水圧計から合力として求めたものであるのでNo.37での 波圧と完全な線形関係ではないが，若干のループを描い てほほ線形的な関係にある. 図-10 から港外側地盤面に は土 $4 \mathrm{k} \mathrm{N} / \mathrm{m}^{2}$ 程度の水圧変動が作用していたことがわか る.

\section{a) 波力と堤体変位}

図-11 (a)〜 (c) に単位幅あたりの波力と堤体変位, 傾 斜角の関係を示寸，堤体の水平変位は図-5(b)の No.59
の変位計での計測值，鉛直変位はNo.61 と No.62 の変位 計の平均值である.

図-11 (a) から波力と変位の関係は押し波側で非線形 性がやや強い傾向がみられ大きな水平変位が発生してい る.

図-11 (b) から波力と傾斜角の関倸は, 図-11 (a)の水平 変位と類似しており，押し波側で非線形性がやや強くな っている. これは，(2)のb)で述べたように，水平変位 のほとんどが堤体の傾斜により生じていたことが原因で ある。

図-11 (c) から波力と平均鉛直変位(負が沈下)の関係は, 波力が押し波でピークになるところでは浮き上がる傾向 が顕著である．また，若干ではあるが引き波のピークで も浮き上がりの傾向にある.

以上から, 波力が押し波のピークで変位, 傾斜が顕著 となり，押し波，引き波のピークになるところで浮き上 がりを示寸傾向があり, これらが図-3で示した負の間隙 水圧の発生に関係すると考える.

\section{b) 波力と鉛直応力, 間隙水圧}

図-12 は単位幅あたりの波力と鉛直応力および間隙水 圧の関係で，鉛直応力と閒隙水圧の値は図-12 (a) では図 -5(b)の No.43 と No.55, 図-12 (b) では No.48 と No.47, 図-12 (c) ではNo.46 と No.45, 図-12 (d) ではNo.4 と No.3, 図-12(e)では No.44 と No.56, 図-12(f) では No.50 と No.49 の土圧計と間隙水圧計の計測值である.

図-12 (a)，(e)から，サクション基礎頂盤近くの港外側 と港内側の隅角の基礎内土（以後, 隅角部）では, 港外 側と港内側のどちらも波力が引き波，押し波のピークの あたりで鉛直応力，間隙水圧が低下している.

特に，押し波時において間隙水圧が低下しているが， これは, 波圧の伝播から考えると矛盾である.すなわち, 押し波時においては，地盤に作用する波圧は増加するの で間隙水圧は増加しなければならない，ところが間隙水

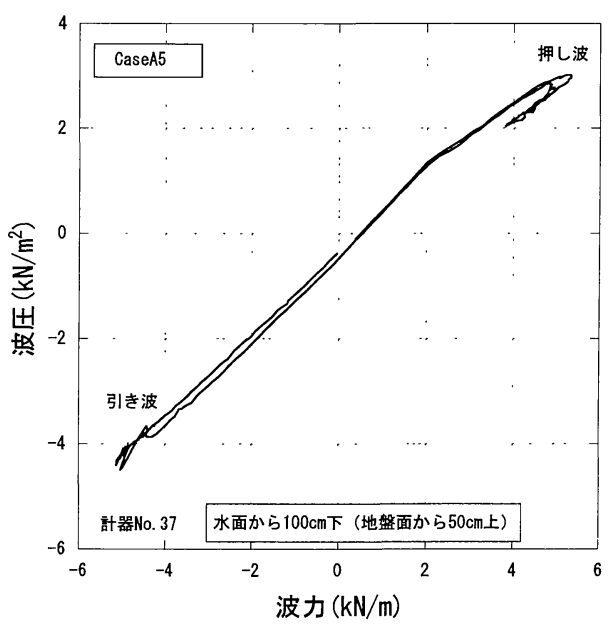

図-10 波力と波圧の関係 


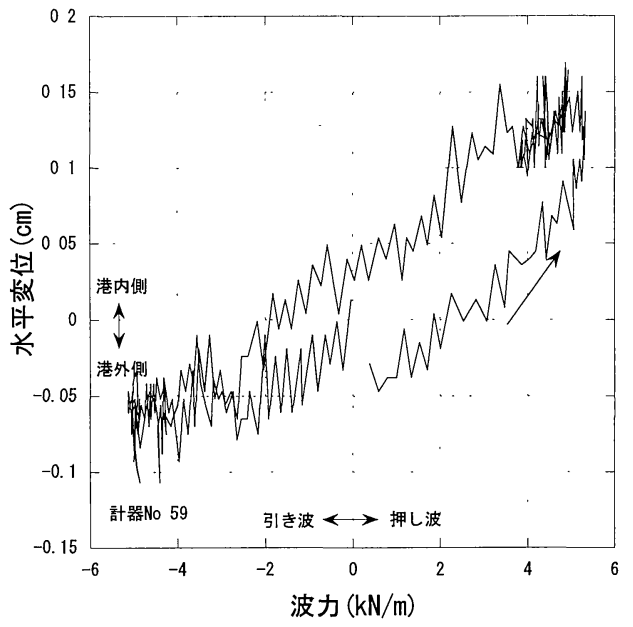

図-11 (a) 波力と水平変位の関係

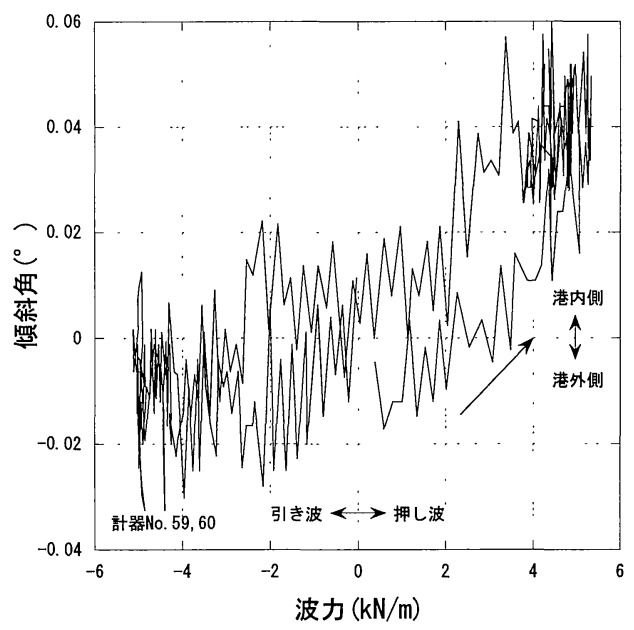

図-11(b) 波力と傾斜角の関係

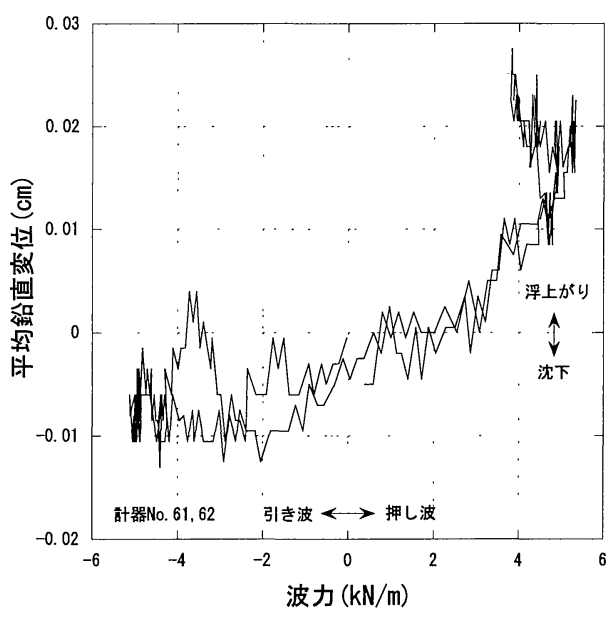

図-11(c) 波力と平均鉛直変位の関係

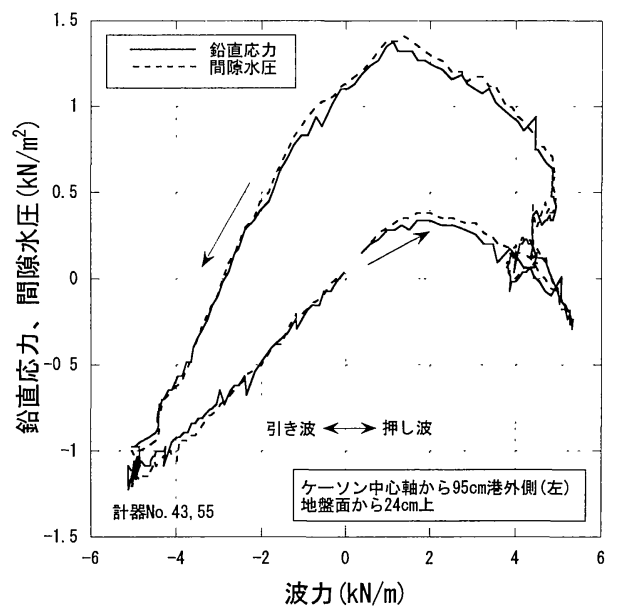

図-12（a）波力と鉛直応力，間隙水圧(港外隅角部)

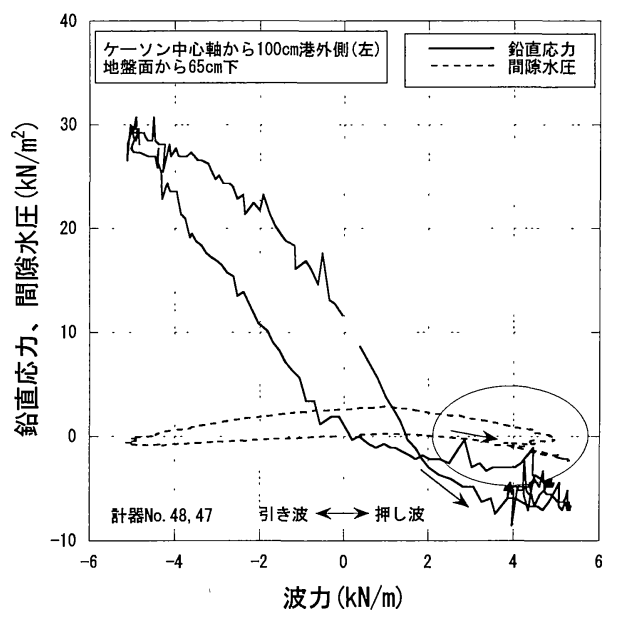

図-12 (b) 波力と鉛直応力, 間隙水圧(港外下端部)

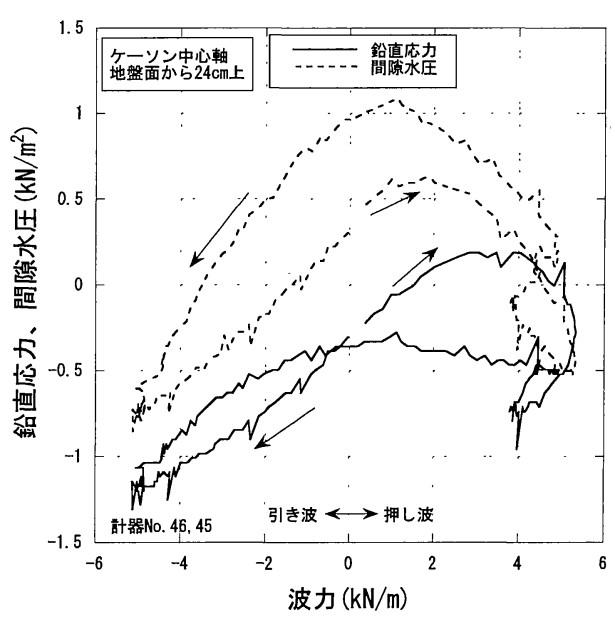

図-12(c) 波力と鉛直応力, 間隙水圧(中央上端部) 


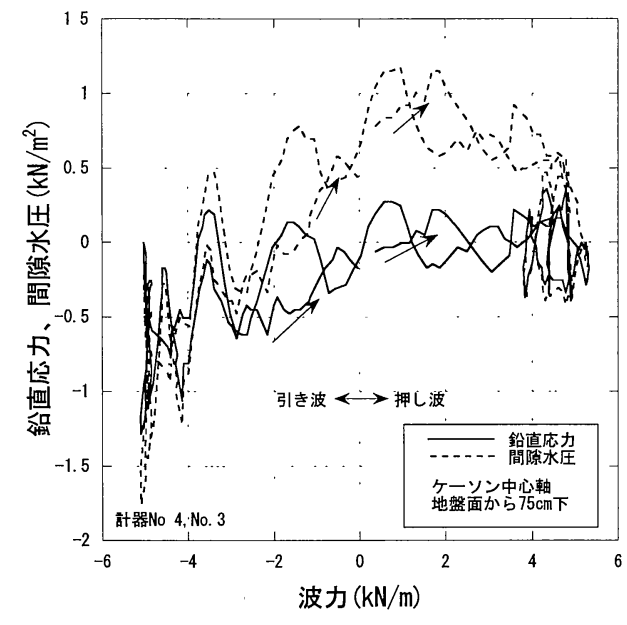

図-12(d) 波力と鉛直応力, 間隙水圧(中央下端部)

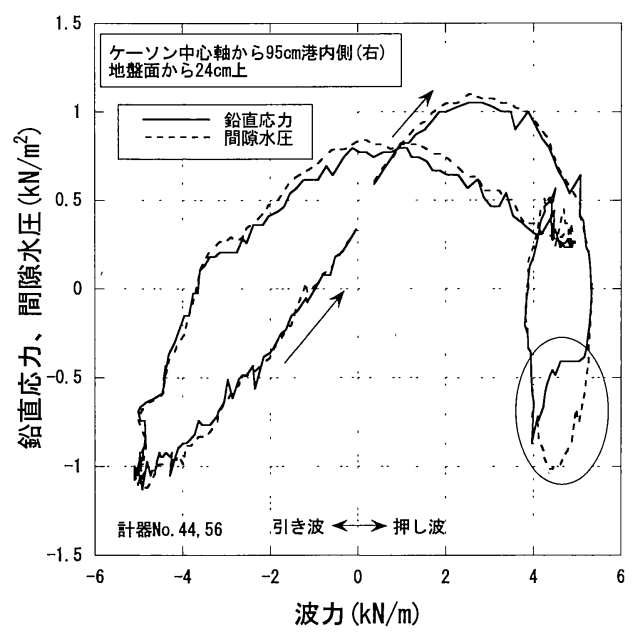

図-12（e） 波力と鉛直応力, 間隙水圧(港内隅角部)

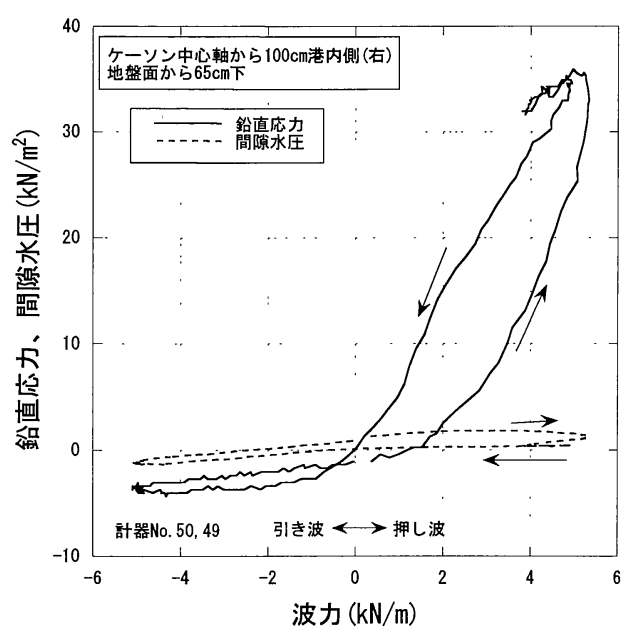

図-12(f) 波力と鉛直応力, 間隙水圧(港内下端部)

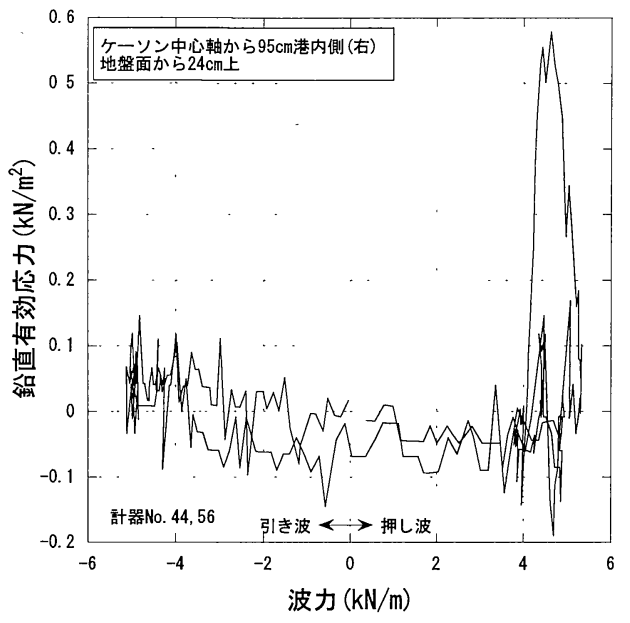

図-13 波力と有効応力の関係(港内側隅角部)

圧は減少を示している.これは前述 a)で示したように堤 体は浮き上がりの傾向があり，2章で示した抜け上がり に抵抗する負の間隙水圧が発生したからであると考える. さらに, 図-12(e)では, 波力が $4 \sim 5 \mathrm{kN} / \mathrm{m}$ で鉛直応力, 間隙水圧が急激に低下しているが，鉛直応力よりも間隙 水圧の低下が大きくなっているところがあり，この部分 では有効応力が急増していることになる. 図-13 は図 -12 (e) の鉛直応力と間隙水圧加有効鉛直応力を求め, 有効鉛直応力と波力の関係を調べたものである. 図-13 から, 波力が-5 +4 k N/m では有効鉛直応力の值はあま り変化していないが，4～ $5 \mathrm{kN} / \mathrm{m}$ で急激に大きくなって いる.これは, 図-9(c)で述べたが, せん断によるダイレ イタンシーに起因した負の間隙水圧が発生したからで, せん断に起因した負の間隙水圧が発生したと考える.ま た, 図-12 (a)，(e)では鉛直応力は間隙水圧とほぼ同じ値 で波力に応答しており,これらのことから, 隅角部では 非排水条件がかなり保たれた状態で波浪に対する応答が 起こっていたといえる.

図-12(b)，(f) から，サクション基礎側壁下端におい ては, 港外側では波力が負になる引き波時, 港内側では 波力が正になる押し波時で鉛直応力は最大值を示す挙動 をしている. 両下端においてそれぞれ鉛直応力が負のと ころ（港外側は押し波時, 港内側は引き波時）では，鉛 直応力の変化は正のところと比較して非常に緩やかであ る.これは, 地盤の引張り抵抗が圧縮抵抗よりも小さく, このことが反映されたといえる. 間隙水圧の波力に対す る応答は鉛直応力の応答と全く異なり, 応答は鈍く, こ のことから側壁下端では頂盤隅角部と比較して排水状態 に近い条件で荷重が作用したと考えられる. また, 前述 の図-12 (a), (e) と同じように引き波時だけでなく押し波 時において, 特に図-12(b)の $2 \mathrm{k} \mathrm{N} / \mathrm{m}$ 以上において，間 隙水圧が減少しており, 負の間隙水圧が発生しているこ 
とがわかる.

図-12 (c)，(d)からサクション基礎中央部の頂盤部と 下端部では, 鉛直応力は, 間隙水圧と絶対値は異なるが, 波力に対する応答の傾向は類似している. また, ここで も引き波だけでなく押し波のピークになるところで, 間 隙水圧は減少傾向にあり, 負の間隙水圧の発生が確認さ れる。

以上から，波力に対してサクション基䃈頂盤部，基礎 下端の基礎内土では，2章で示した全応力の変化に基づ く負の間隙水圧とせん断に起因した負の間隙水圧の 2 種 類が発生していることが確認された. また, 波力に対し てサクション基礎頂盤部の基礎内土では非排水条件に近 い状態で, 基礎下端では排水条件に近い状態で荷重載荷 が行われている.

\section{4. 数値計算による実験結果の検討}

ここでは数值計算プログラムを用い, 実験で得られた 地盤内の応力, 間陌水圧の応答結果の検討を行う. 検討 は, せん断によるダイレイタンシーに起因した負の間隙 水圧は対象とせず，引き抜きに対して抵抗して発生する 負の間隙水圧の検討を目的に, 土を弾性体と仮定した比 較的簡単な要素モデルを用いて行う.

\section{(1) 有限要素モデル}

\section{a) 使用したプログラム}

使用したプログラムは, 朴らの開発した 2 次元の有限 要素プログラムである ${ }^{14)}$. 詳細は参考文献 ${ }^{14)}$ を参照され たいが，主な特徵は以下のとおりである.

・計算は時間領域での計算ではなく, 周波数領域での計 算である.

・土要素の応力ひずみモデルは履歴减衰を考慮した弾性 体を仮定しており, 剛性率 $G$, ポアソン比 $\nu$ と減衰比 $h$ がパラメータとなる. ただし, SHAKE などと異なり, プログラムでは計算中に有効ひずみとせん断岡性率の関 係が骨格曲線を満たすようには絽返し計算を行なってい ない. したがって, 計算は剛性率および咸衰定数が入力 値と同じ値の一定值で行われる.

・基礎式は, 海底地盤上の水 (海) の部分はポテンシャ 儿理論により定式化され，海底地盤は気泡の混入を考慮 した圧縮性流体で満たされている多孔質弾性体を仮定し た Biot の二相弾性理論により定式化されている. また, 土粒子部分と間隙水の加速度項も考慮されている.

\section{b) 模型実験のモデル化}

水路の地盤部と水部を 618 個の要素で分割してモデル 化した. 図-14 には地盤部（実線，'堤体本体は太実線), 水部（点線）の主要部分を示す。ここで, 実験で用いた
サクション基礎は円筒で断面が円形であるため, 矩形断 面に換算する必要がある. 矩形への換算は断面 2 次モ一 メントが等しくなるように行い ${ }^{8)}$, その結果モデルの幅 は $1.73 \mathrm{~m}$ とサクション基礎直径 $2 \mathrm{~m}$ の約 9 割の長さにな っている.

パラメータは, 地盤定数については, 土の湿潤単位体 積重量を $\gamma_{\mathrm{t}}=19 \mathrm{k} \mathrm{N} / \mathrm{m}^{3}$, 間隙率を $n=0.4$, 透水係数 $k=0.05 \mathrm{~cm} / \mathrm{s}$ とした. 地盤内の間隙水の体積弾性係数につ いては，実験での隅角部の間隙水圧が鉛直応力とほぼ等 しく応答していたことから, Skempton の間隙圧係数 $\mathrm{B}^{15}$ を 0.95 と仮定して設定した. ここで, 地盤の変形係数の 設定は以下のようた考えて設定した. 水路実験で発生し た傾斜角が地盤に発生しているせん断ひずみに相当する と仮定すると, $10^{-3}$ のオーダーのひずみが発生していた ことになる. そこで, 有効拘束圧, 間隙比, ひずみ振幅 から剛性率を求める経験式 ${ }^{16)}$ を利用して図-14 に示した 各層に対して剛性率を算出した. その結果, 剛性率は深 さ方向に増加し, $G=1670 \sim 8050 \mathrm{kN} / \mathrm{m}^{2}$ の值となった. な お, 上部堤体からの圧力（ケーソン重量基礎底面積 $=2.2$ $\mathrm{kN} / \mathrm{m}^{2}$ ) による応力増加は考慮しなかった. また, 減衰 定数についてもひずみ振幅 $10^{-3}$ に対応する経験值 ${ }^{16)}$ を用 いて $h 0.1$ とした. ポアソン比は $\nu=0.3$ を仮定した. 堤 体とサクション基礎本体については地盤より十分硬く, また透水係数が小さくなるように, $G=10^{5} \mathrm{kN} / \mathrm{m}^{2}$, $\gamma \overline{\mathrm{t}} 21 \mathrm{kN} / \mathrm{m}^{3}, \quad \nu=0.3, n=0.01, k=1.0 \times 10^{-7} \mathrm{~cm} / \mathrm{s}$ と仮定し た.

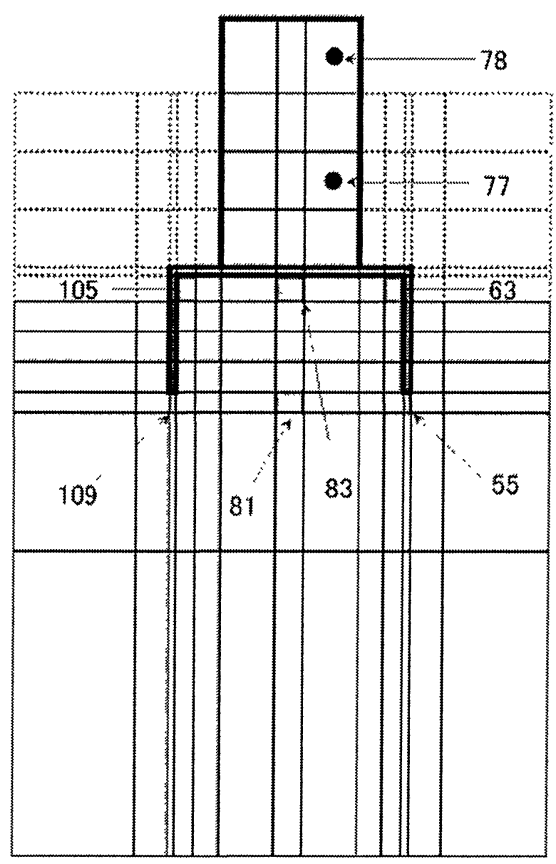

図-14 有限要素メッシュの主要部分 
表-3＼cjkstart要素とセンサーの位置関係

\begin{tabular}{|c|c|c|c|c|c|c|}
\hline \multicolumn{3}{|c|}{ 訐焣での座標位置(図-14) } & \multicolumn{3}{|c|}{ 実験での座標位㻼(図-5(b)) } & \multirow[b]{2}{*}{ 備考 } \\
\hline 要素No. & $\begin{array}{l}\text { 水平(中心か } \\
\text { らの距離) }\end{array}$ & 鉛直(地盤面 & センサーNo & 水平(中心か & 鉛直(地盤面 & \\
\hline No.78 & $30 \mathrm{~cm}$ & $177 \mathrm{~cm}$ & No.59 & $50 \mathrm{~cm}$ & $174 \mathrm{~cm}$ & 上部変位 \\
\hline No.77 & $30 \mathrm{~cm}$ & $87 \mathrm{~cm}$ & No. 60 & $50 \mathrm{~cm}$ & $74 \mathrm{~cm}$ & 下部変位 \\
\hline No. 105 & $-75 \mathrm{~cm}$ & $10 \mathrm{~cm}$ & No. 43,55 & $-95 \mathrm{~cm}$ & $24 \mathrm{~cm}$ & 港外側隅角 \\
\hline No.109 & $-84 \mathrm{~cm}$ & $-73 \mathrm{~cm}$ & No. 48,47 & $-100 \mathrm{~cm}$ & $-65 \mathrm{~cm}$ & 港外側下端 \\
\hline No.83 & $0 \mathrm{~cm}$ & $10 \mathrm{~cm}$ & No.46, 45 & $0 \mathrm{~cm}$ & $24 \mathrm{~cm}$ & 中央部上端 \\
\hline No.81 & $0 \mathrm{~cm}$ & $-73 \mathrm{~cm}$ & No.4,3 & $0 \mathrm{~cm}$ & $-75 \mathrm{~cm}$ & 中央部下端 \\
\hline No.63 & $75 \mathrm{~cm}$ & $10 \mathrm{~cm}$ & No. 44,56 & $95 \mathrm{~cm}$ & $24 \mathrm{~cm}$ & 港内側隅角 \\
\hline No. 55 & $84 \mathrm{~cm}$ & $-73 \mathrm{~cm}$ & No. 50,49 & $100 \mathrm{~cm}$ & $-65 \mathrm{~cm}$ & 港内側下端 \\
\hline
\end{tabular}

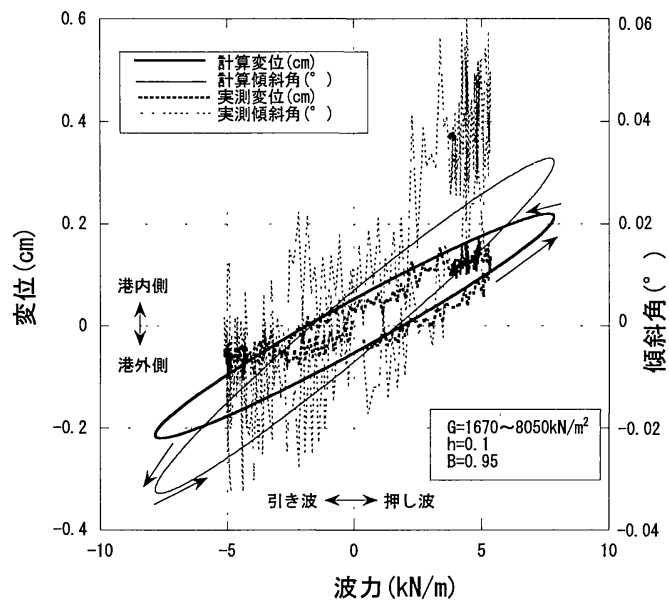

図-15(a) 波力と変位，傾斜角の関係

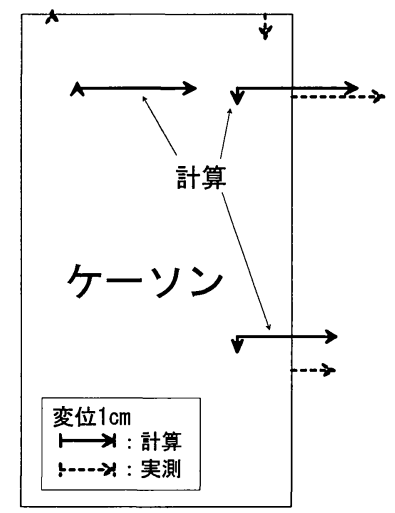

図-15(b) ケーソンの変位ベクトル

入力する波浪は正弦波で，波高と周期は水路実験での CaseA5 のものを用い，波高 $58.9 \mathrm{~cm}$ ，周期 $2.5 \mathrm{~s}$ とした.

以降の計算結果については, 図-14 の番号で示寸各要 素の中心での值で検討することにする，各要素中心と対 応する実験でのセンサーは，表-3のような位置にある.

\section{(2) 計算結果}

\section{a) 波力と変位, 傾斜角の関係}

図-15(a)は，ケーソンーサクション基礎に作用した波
力と水平変位およひ傾斜角の関係を図-11 (a), (b) の実測 值とともに示したもので, 計算值は実線, 実測值は点線 で，それぞれ水平変位は太線，傾斜角は点線である。 ま た，図-15(b) はケーソンの変位ベクトル図である，計算 水平変位は図-14 の No.78 の要素中心の值で, 図-5(b)の No.59 での変位計の位置にほぼ対応するものである. 傾 斜角は図-14 の No.78 と No.77 の要素中心の変位から算 出したものである.

図-15 を実測值と比較すると，計算から得られた波力 は-8〜 $+8 \mathrm{k} \mathrm{N} / \mathrm{m}$ で実測值の-5 +5 k N/m より大きめの值 になっている．計算結果は，変位については実測值より 大きめ, 傾斜角については実測值より小さめであるが, 実測值とほぼ対応しているといえる. このように計算結 果が実測值とほぼ対応したのは, 水路実験で発生した地 盤内のひずみをケーソンーサクション基礎の傾斜角から 仮定し，これを用いて岡性率を設定したことが大きな原 因と考えられる. したがって, 地盤の岡性率は妥当な值 が設定されたと考える. しかしながら，実際に波浪時の シミュレーションを行う場合には事前に発生ひずみを知 ることはできず，このような方法で岡性率の設定を行う ことはできないので, より高度な解析法を検討すること が今後の課題である.

\section{b) 波力と鉛直応力, 間隙水圧の関係}

図-16の太線は, 計算から得られた波力と鉛直応力 (実 線), 間隙水圧 (点線)の関係である. 各計算値は, 図-16 (a) は図-14のNo.105, 図-16 (b) はNo.109, 図-16 (c) はNo.83, 図-16 (d) はNo.81, 図-16 (e) はNo.63, 図-16 (f) はNo.55 の要素中心での值で,それぞれ実測の図-12(a)〜 (f) に対 応する箇所のもので，実測値は細線で併せて示されてい る.

図-16 (a)，（e)から，隅角部では間隙水圧は鉛直応力 とほぼ同じ值で波力の変化に応答している. 間隙水圧と 鉛直応力の最大值での比をどると, 図-16 (a) では 0.75, 図-16(e) では 0.83 となっている. B 值を 0.95 と設定した ことに対し間隙水圧と鉛直応力の比が 0.95 に近くなって いることから，比較的非排水条件が保たれた状態で外力 に応答しているといえ，このことについては，実測值と 良い対応である. しかし，計算值と実測值ではループの 形状はかなり異なっている，すなわち，実測值では押し 波，引き波のピークで鉛直応力，間隙水圧は低下してい たが，計算值では図-16（a)では押し波時，図-16(e)では 引き波時にしか鉛直応力，間隙水圧は減少していない．

この違いの原因は以下のように説明できる.

まず，港外側については，計算結果は，図-16(a) で波 力が負，すなわち波圧が負のときに鉛直応力と間隙水圧 は増加して正の值になり，実測值では負の值になってお り対応していない．これは，引き波時に堤体港外側が地 盤に押し付けられるモードになり，港外側基礎に 


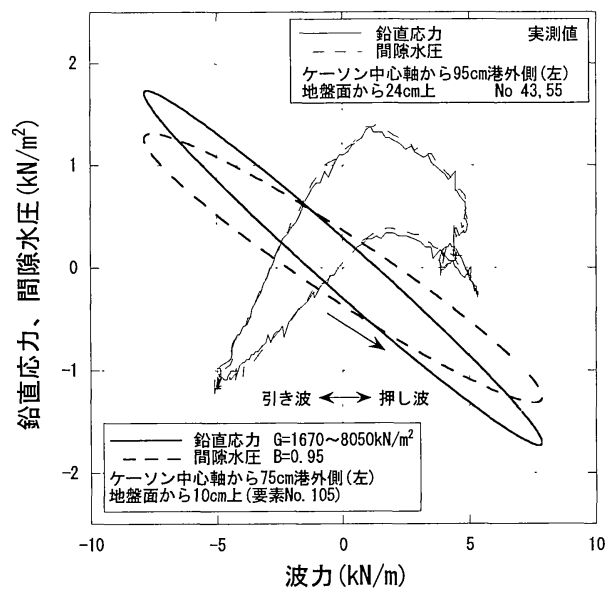

図-16（a） 波力と鉛直応力, 間隙水圧(港外隅角部)

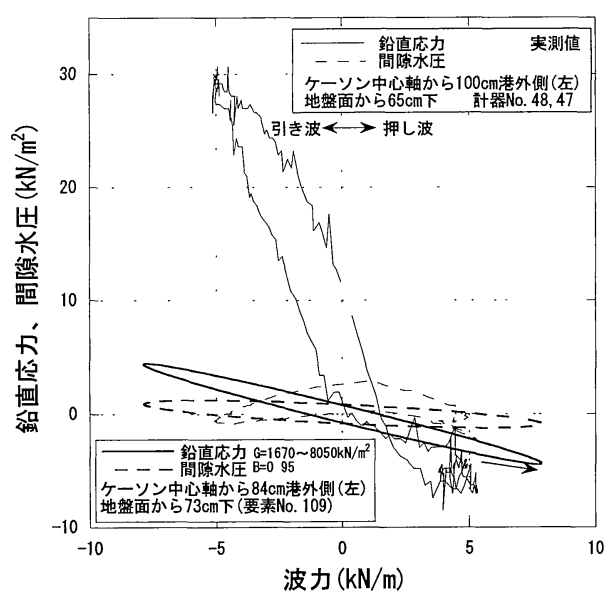

図-16(b) 波力と鉛直応力, 間隙水圧(港外下端部)

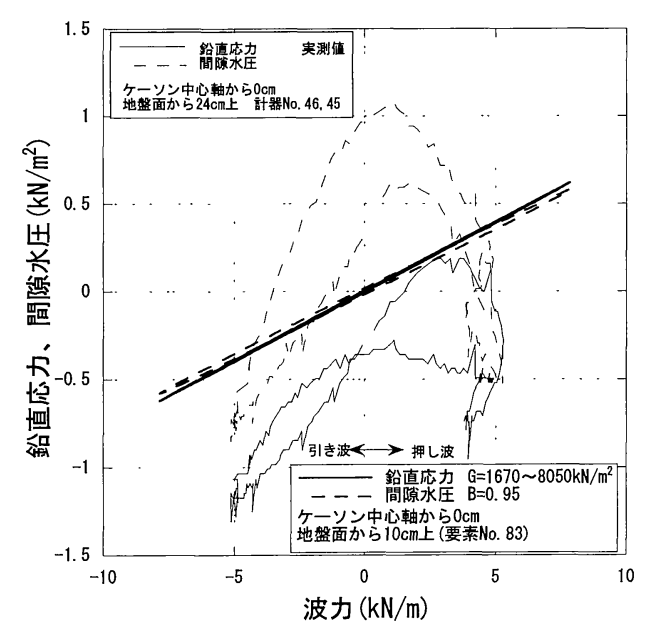

図-16（c）波力と鉛直応力，間隙水圧(中央上端部)

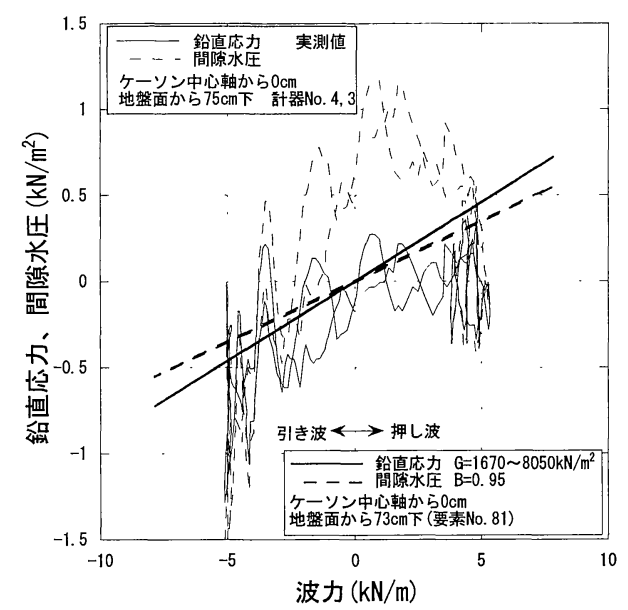

図-16 (d) 波力と鉛直応力，閒隙水圧(中央下端部)

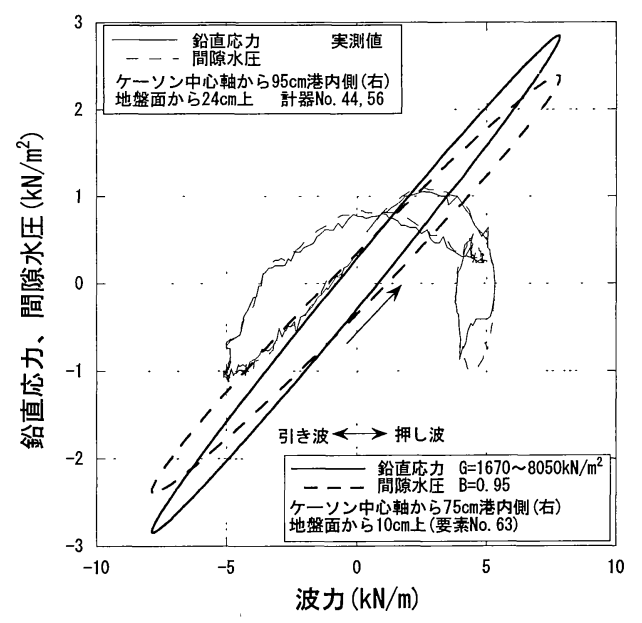

図-16（e） 波力と鉛直応力，間隙水圧(港内隅角部)

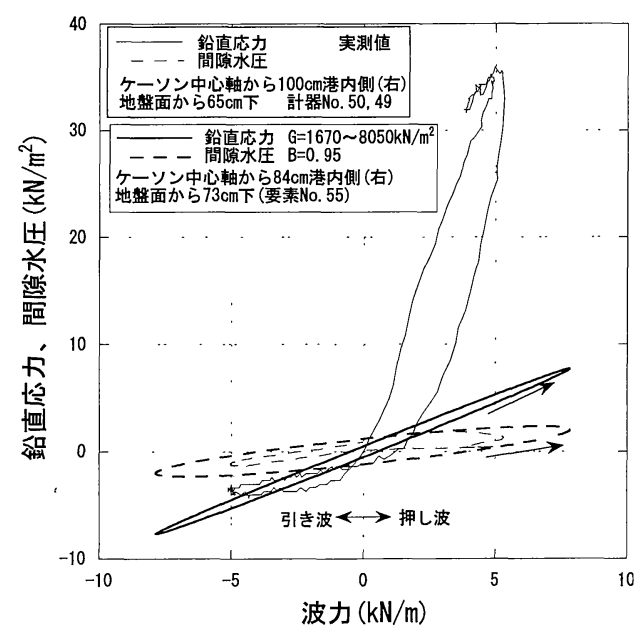

図-16(f) 波力と鉛直応力, 閒隙水圧(港内下端部) 
かかる荷重が増加し, 計算結果ではこれに応答して鉛直 応力, 間隙水圧が増加したと説明される. すなわち, 計 算では図-3で説明した逆の現象が起こったと考える. と ころが，実測值では，図-16(b)をみると港外側基礎下端 の実測值は計算值よりも大幅に鉛直応力が増加しており, 押込みによる荷重増加の多くは港外側基礎側壁を介して 直接基礎下端に伝達され，隅角部での鉛直応力の増加に は寄与していなかったといえる. したがって, 図-16(a) の実測值では波力に対する堤体の応答よりも波圧の伝播 が顕著となり, 引き波時に間隙水圧, 鉛直応力が低下し たと説明される. この違いが計算結果と実測值の違いに 現れたと考える. 一方，押し波時については波力により 港外側の堤体は抜け上がろうとし, 計算では基礎頂盤部 の鉛直応力, 間隙水圧は低下し, 負の間隙水圧が発生し たと考える. 実測值についても, 波力が $2 \mathrm{k} \mathrm{N} / \mathrm{m}$ 程度ま では波圧伝播が顕著で鉛直応力, 閒隙水圧は増加傾向で あるが，波力が $2 \mathrm{kN} / \mathrm{m}$ 以上のところでは減少しており， 基礎の抜け上がりに対する応答が顕著になり負の間隙水 圧が発生したと考える.このように押し波時には引き波 時よりも計算値と実測值が対応したのは, 図-16(b)をみ ると基礎下端では引き波時ほど実測值が計算値と大きく 異なることはなく, 隅角部に作用する引き抜き荷重が計 算と実測で大きく違わなかったからである.

次に港内側については, 引き波時に堤体は抜け上がり, 押し波時に地盤を押し付けるモードとなる. したがって， 隅角部の鉛直応力と間隙水圧は, 引き波時に引き抜き力 が作用して低下し，押し波時に押込み力により増加する. また, 波圧の伝播に対しても, 引き波時に鉛直応力, 間 隙水圧は減少し, 押し波時に増加する. 計算結果では, この両者が反映され，図-16(e)に示寸結果となったと考 える. ところが，実測值では押し波時のピーク付近で減 少傾向になっている. これは, 次のようなことが起こっ ていると考えられる. 港外側基礎下端の図-12(f) では波 力が $2 \mathrm{k} \mathrm{N} / \mathrm{m}$ を超えるところで鉛直応力は急増し, また, 図-11 (c) で示したように波力が $2 \mathrm{kN} / \mathrm{m}$ を超えるところ では，堤体，基礎全体としては大きく抜け上がろうとし ている. したがって, 基礎下端を支点とした回転モード で基礎全体が抜け上がろうとし，押し込まれる側ではあ るが隅角部はこれに応答して鉛直応力, 間隙水圧が減少 したと思われる. 計算ではこのような基礎全体が抜け上 がる回転モードが評価できていない.さらに, 港外側で も述べたが，図-16(f)に示すように実測では押込み時に 鈆直荷重の多くが基礎内土を介さず基礎側壁を介して基 礎下端に伝播するが, 計算ではこのことが適切に評価で きておらず，実測值と比較して隅角部で大きめの鉛直荷 重が加わっている. これらの点が港内側での計算結果と 実測値の違いになったと考える.

以上から, 隅角部の鉛直応力と間隙水圧の挙動につい
ては, 波力の作用に対して押し込まれる側である場合(港 外側：引き波時, 港内側 : 押し波時）には計算結果は実 測值の傾向を説明できないが, 引き抜かれる側である場 合（港外側：押し波時，港内側：引き波時）には比較的 説明できていると考える. また，排水性についても良い 対応であったといえる.

基礎下端については, 図-16(b)，(f) から, 計算值の 間隙水圧の波力（外力）に対する応答は鉛直応力の半分 以下であることがわかる，したがって，図-16(a)，(e) で示した隅角部よりは排水条件に近い状況で応答してお り，また実測值が排水条件に近い状況にあることと対応 している. また, 隅角部と同じく, 基礎下端が引き抜か れる側である場合（港外側：押し波時, 港内側 : 引き波 時）には鉛直応力と間隙水圧は低下しており実測值と対 応しているが，押し込まれる側である場合（港外側 : 引 き波時, 港内側 : 押し波時) には実測值の傾向は説明で きておらず, 鉛直応力の挙動には大きな違いがある.こ れは隅角部のところで既に述べたように，実測の方では 基礎にかかる荷重の大部分が側壁を介して基礎下端に作 用するが，計算ではこのことが過小評価されているから である.

図-16 (c), (d) から, 基礎中心部では計算值の鉛直応 力, 閒隙水圧は波力と同じように増減している.これは, 基礎中心部では中立位置であるので波力の作用による抜 け上がりや押込みの影響が大きく現れず，波圧の伝播の 影響が強く現れているといえる. しかし，実測值では, 押し波時でも鉛直応力, 間隙水圧は低下しており, 計算 值と対応していない.これは, 図-11 (c) で示したように 実測では押し波時のピーク付近で堤体全体が大きく抜け 上がろうとしており，これに対する応答が大きく現れて 鉛直応力, 間隙水圧が低下していると考えられる.

以上から, 波力に対する地盤の排水性については，基 礎頂盤付近では間隙水圧は非排水状態が保たれ，基礎下 端では排水状態に近くなっており，計算と実測は比較的 良く対応していたといえる. また，鉛直応力の応答は， 抜上がり側となる場合には計算と実測の挙動は対応して おり，抜上がりで発生する負の間隙水圧を表現できたと いえる.しかし，押し込まれる側については全く説明で きておらず，実現象では地盤の土の非線形性に基づく現 象や，基礎側壁と地盤のすべりなどを含め, 数值計算モ デルより複雑なことが起こっていると考えられる.これ らも負の間隙水圧の発生に定量的に影響していると推察 され，数値計算で実測值の挙動を精度良く定量的に表現 するには，土要素の応力・ひずみモデルだけでなく，基 礎本体の側壁と地盤で接合モデルなどを取り入れ，より 高度にする必要がある. 


\section{5. 外力, 地盤の排水性と負の間隙水圧の関係}

ここでは，水理実験の CaseA5 を 3章で検討しなかつ た波力の小さい CaseA1 の実験結果と比較して外力の大 きさと発生する負の間隙水圧の関係，また4章の数值計 算法を用いて地盤の排水性と発生する負の閒隙水圧の関 係を考察する.

\section{(1) 外力の大きさと負の間陌水圧発生の関係}

波高が設計波高の $58.9 \mathrm{~cm}$ で行った CaseA5 の港外側隅 角部では図-12(a)に示したように，押し波時に基礎の抜 け上がりに抵抗して負の間隙水圧が発生したことを述べ た.これを，波高の小さな CaseA1 と比較する. CaseA1 では波高 20cm がかけられ，図-17 が図-12(a)に対応する 波力と鉛直応力, 間隙水圧の関係である. CaseA5 と同じ く，間隙水圧は波力の作用に対して鉛直応力とほぼ同じ 值で変化していることがわかる. しかし, CaseA5 で見ら れたような押し波側での閒隙水圧，鉛直応力の低下は見 られない.これは, CaseA1 では波高が小さく外力が小さ いために, CaseA5 と比較して押し波時の基礎の抜け上が り傾向が顕著でなかったからであると考えられる.図-18 は CaseA1 での堤体の平均鉛直変位（浮上がりが正）と 波力の関係を調べたもので, CaseA5 の図-11(c) と比較す ると押し波時での抜け上がりはほとんど見られない.さ らに間隙水圧と平均鉛直変位の関係を調べたのが, 図-19 と図-20 である. 図-19 は CaseA5, 図-20 は CaseA1 のも ので，それぞれ港外側での基礎頂盤と基礎下端について のものである. 図-19 から，CaseA5 では基礎頂盤部，基 礎下端のどちらにおいても平均鉛直変位が $0 \mathrm{~cm}$ から $+0.02 \mathrm{~cm}$ になるところで, 間隙水圧は減少を示している. 平均鉛直変位が $0 \mathrm{~cm}$ から+0.02cm のところは図-11 (c) で 示されたように，波力は押し波であり圧力伝播の観点か

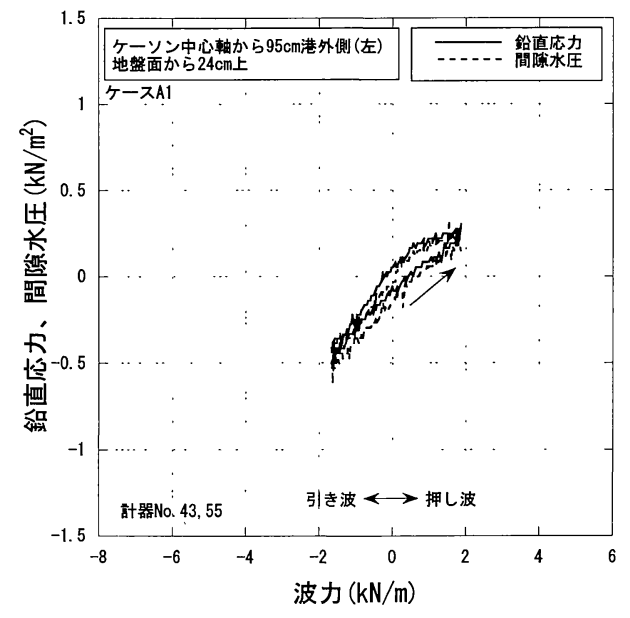

図-17 波力と鉛直応力, 間隙水圧の関係(CaseA1)

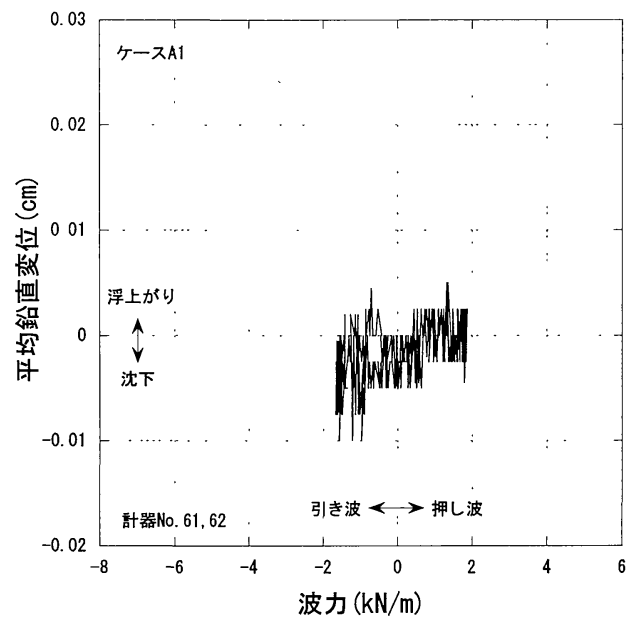

図-18 波力と平均鉛直変位の関係(CaseA1)
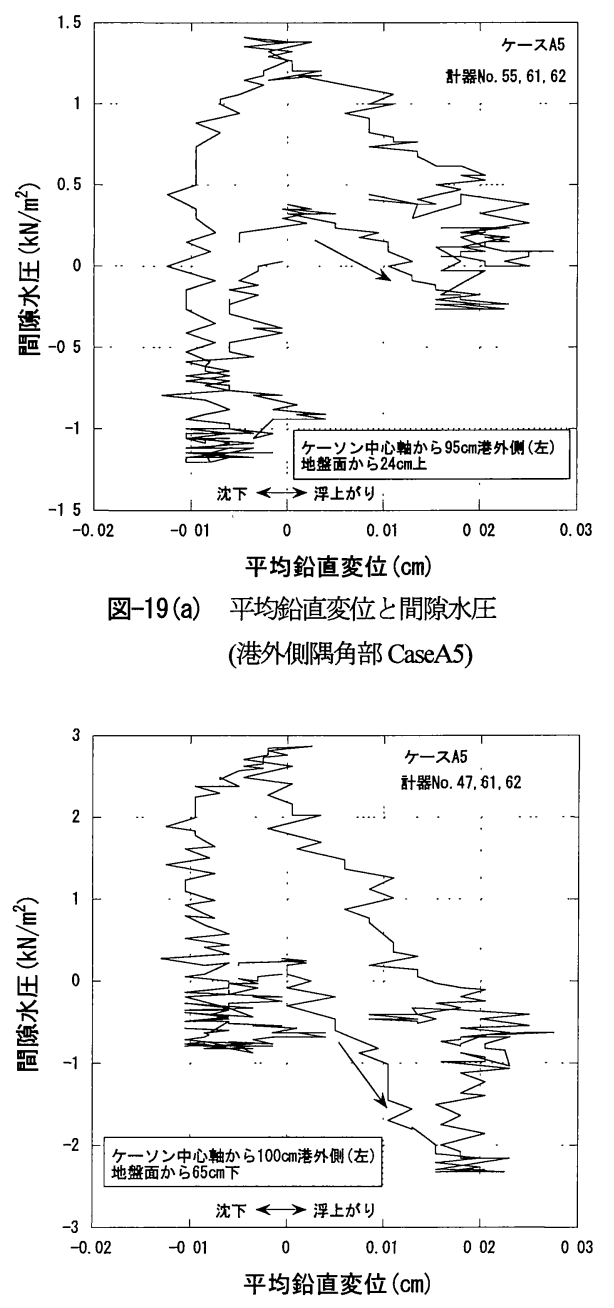

図-19(b) 平均鉛直変位と間隙水圧 (港外側下端部 CaseA5) 


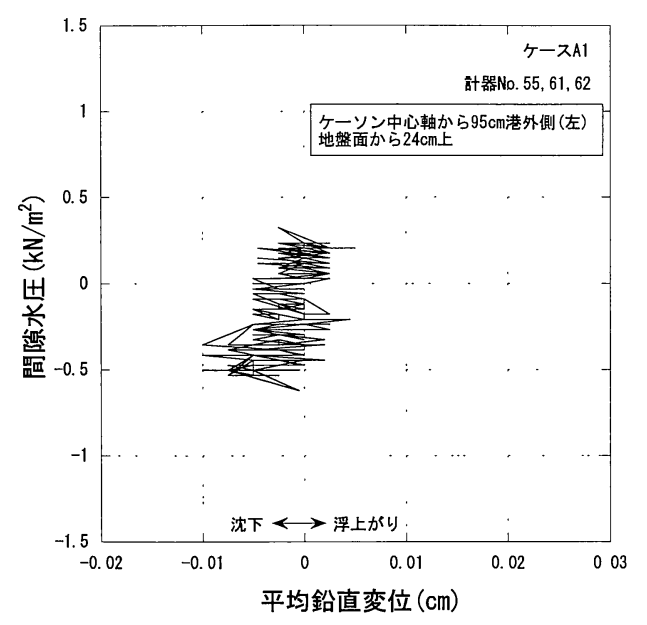

図-20(a) 平均鉛直変位と閒隙水圧 (港外側隅角部 CaseA1)

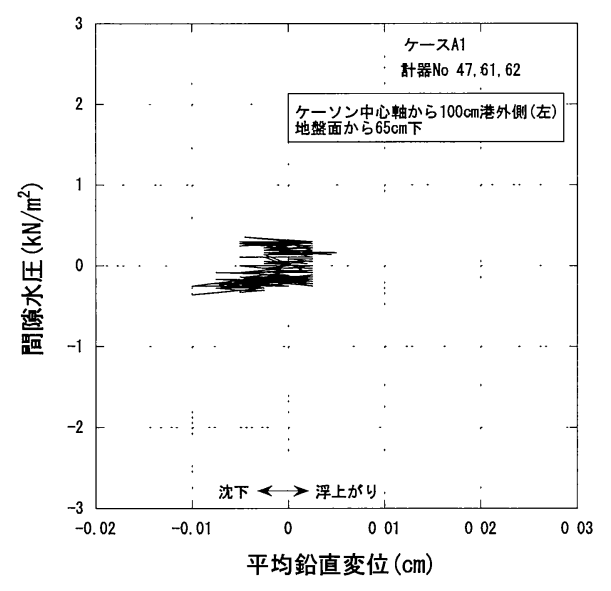

図-20(b) 平均鉛直変位と間隙水圧 (港外側下端部 CaseA1)

らみると間隙水圧は上昇しなければならず，ここでの間 隙水圧の減少は基礎の抜け上がりに抵抗して発生した負 の間隙水圧である. 一方, CaseA1 については図-20から 平均鉛直変位が正で大きくなることはなく，基礎の抜け 上がりに抵抗して間隙水圧が減少することはないことが わかる. 以上から, サクション基礎に対して水平力が作 用し基礎が抜け上がろうとすると負の間隙水圧が発生す ることが鉛直変位との関係で示された. そして, 負の間 隙水圧の発生は外力が大きく変位が大きくなる場合に顕 著となる.

次に, CaseA5 では図-12(e), 図-13 で示したように港 内側隅角部でせん断のダイレイタンシーに起因した負圧 の発生が見られた．2章で述べたように，これは前述の 抜け上がりに抵抗して発生する負の間隙水圧とは異なる ものである. すなわち前述の場合には非排水条件下での

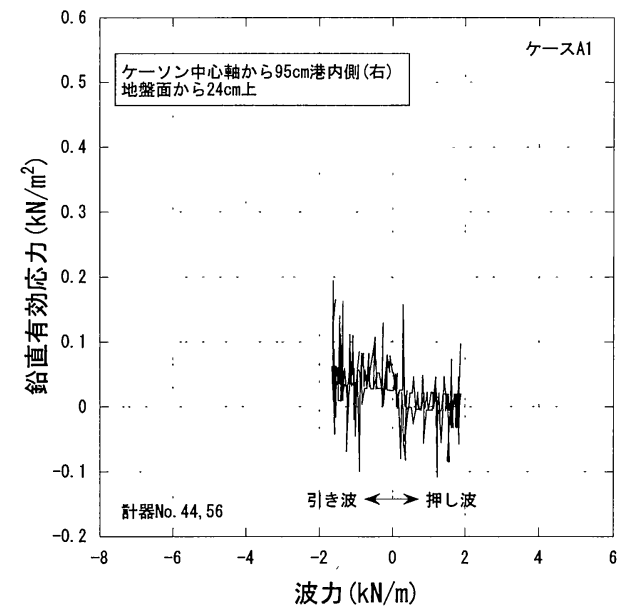

図-21 波力と鉛直有効応力の関係(CaseA1)

全応力の変化に基づくもので, 土要素で体積変化が起き ないためには有効応力が一定に保たれる必要があり, 全 応力の減少に対しては間隙水圧が減少するというもので ある. しかし，ここでの負圧は全応力の変化に起因する のではなく, せん断によるダイレイタンシー (体積膨張) に対して体積変化が生じないように有効応力が増加する ために間隙水圧が減少し負の間隙水圧になるというもの である.したがって，ダイレイタンシーに起因した負の 間隙水圧が発生するところでは有効応力は増加すること になり, 図-13 において波力の変化に対して有効応力が 大きく増加する部分が見られた. CaseA1 の実験に対して 図-13 と同様に整理したものが図-21 である. 図-21にお いて, 有效応力には波力の変化に対してノイズのような ものが見られるが，図-13 のように明確な有効応力の増 加は見られない. したがって, CaseA1 ではせん断による ダイレイタンシーに起因した負の間隙水圧は発生してい ないといえ, 外力が大きくなった場合にダイレイタンシ 一に起因した負の間隙水圧が発生することがわかる.

以上, CaseA5 と CaseA1 の比較から, 地盤に残留変形 が生じる程度まで外力が大きくなった場合に負の間隙水 圧の発生は顕著となり, 負の間隙水圧は基礎が変位する ことに対して発生し抵抗となっているといえる.

\section{（2）排水性と負の間隙水圧発生の関係}

負の間隙水圧発生のためには完全である必要はない が，2章で示したように非排水条件が保たれねばならな い. 数值計算では, 実験結果について排水状態と基礎が 抜け上がる側での鉛直応力, 間隙水圧挙動をある程度説 明できており，これらの点について数值計算で負の閒隙 水圧の発生に関して考察が可能と考える. ここでは, 透 水係数を変化させて数值計算を行い, 排水性と負の間隙 水圧の発生の関係を考察する。 


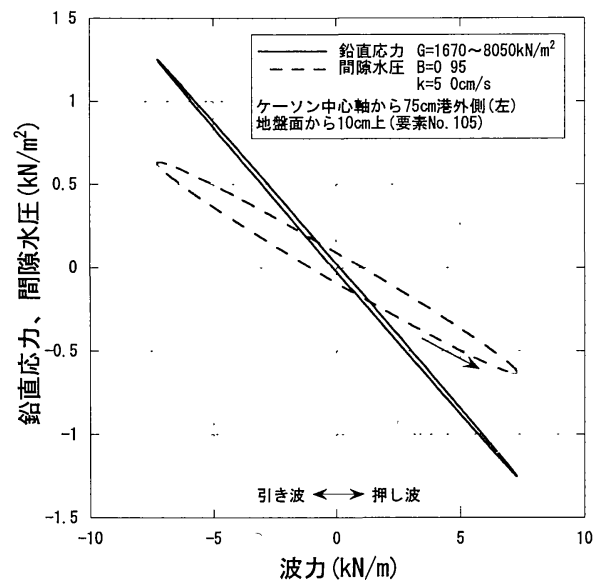

図-22(a) 波力と鉛直忘力間隙水圧 (港外側隅角部 $k=5 \mathrm{~cm} / \mathrm{s}$ )

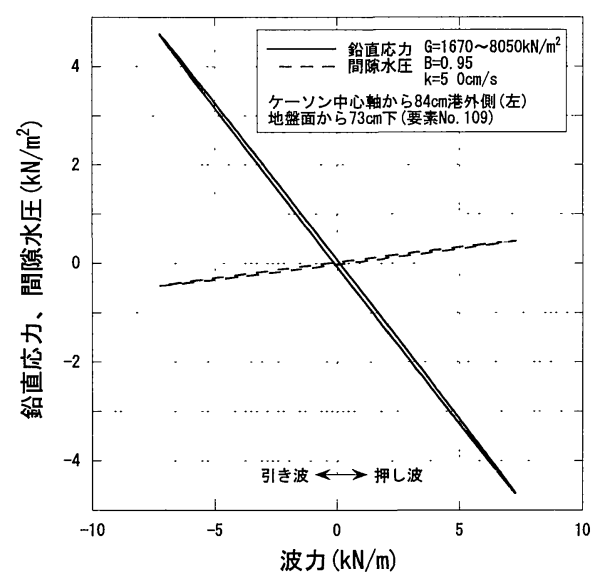

図-22(b) 波力と鉛直応力間隙水圧 (港外側下端部 $k=5 \mathrm{~cm} / \mathrm{s}$ )

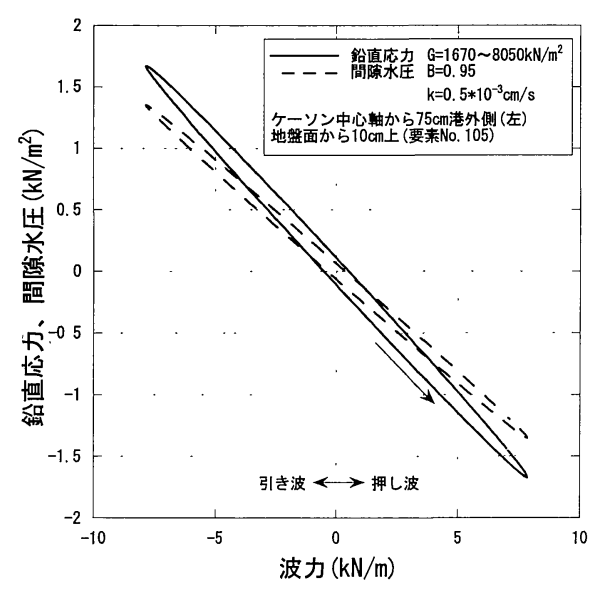

図-22(c) 波力と鉛直応力間隙水圧 (港外側隅角部 $k=0.0005 \mathrm{~cm} / \mathrm{s}$ )

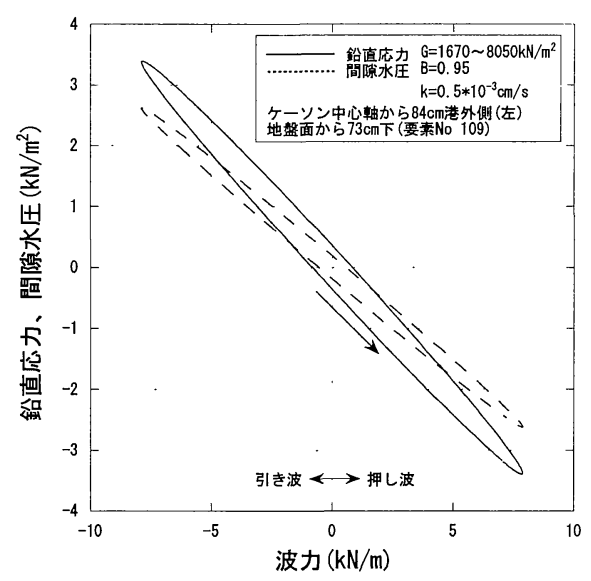

図-22(d) 波力と鉛直応力間隙水圧 (港外側下端部 $k=0.0005 \mathrm{~cm} / \mathrm{s}$ )

数值計算では, 透水係数を 4 章で用いた $k=0.05 \mathrm{~cm} / \mathrm{s}$ に 対して, $k=5 \mathrm{~cm} / \mathrm{s}$ と $k=0.0005 \mathrm{~cm} / \mathrm{s}$ と大小それぞれ 2 オー ダー変えて計算を行った. その他のパラメータは同一で ある.

図-22 は, 透水係数が $k=5 \mathrm{~cm} / \mathrm{s}, k=0.0005 \mathrm{~cm} / \mathrm{s}$ の場合の 港外側の隅角部(図-14のNo.105)と下端部(No.109)の計算 結果である. 透水係数が $k=5 \mathrm{~cm} / \mathrm{s}$ では，押し波のピーク の波力が $8 \mathrm{kN} / \mathrm{m}$ において, 隅角部(図-22(a))で鉛直応力

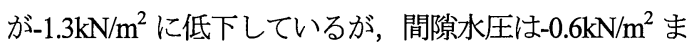
でしか低下していない，下端部(図-22(b))においては， 鉛直応力は- $4.7 \mathrm{kN} / \mathrm{m}^{2}$ まで低下しているが，間隙水圧は $+0.5 \mathrm{kN} / \mathrm{m}^{2}$ に増加している. したがって, 透水係数が $k=5 \mathrm{~cm} / \mathrm{s}$ では排水性が良いために，抜け上がりによる負 の間隙水圧は発生せず基礎下端では波圧の伝播が顕著に なり正の間隙水圧になったといえる. しかし，隅角部で は比較的非排水条件が保たれ，抜け上がりで鉛直応力が 減少する内の 5 割程度が負の間隙水圧となっている. 透 水係数が $k=0.0005 \mathrm{~cm} / \mathrm{s}$ の場合には，隅角部(図-22(c))に おいて鉛直応力は- $1.7 \mathrm{kN} / \mathrm{m}^{2}$ まで低下し，間隙水圧は $-1.4 \mathrm{kN} / \mathrm{m}^{2}$ まで低下している.下端部(図-22(d))では, 鉛 直応力は-3.4 k N/m $\mathrm{m}^{2}$ まで低下し，間隙水圧は-2.6 $\mathrm{kN} / \mathrm{m}^{2}$ ま で低下している. したがって, $k=0.0005 \mathrm{~cm} / \mathrm{s}$ ではかなり 非排水条件が保たれ，大きな負の間隙水圧が発生してい るといえる.

負の間隙水圧の発生と透水係数の関倸を, 間隙水圧比 と透水係数の関係で基礎の各部分について調べたのが図 -23 である. ここでの間隙水圧比は間隙水圧と鉛直応力 の比で，各部分が抜け出し時になるように港外側では押 し波時，港内側では引き波時をとった．中立となる基礎 中心線部では押し波時を採用した. 図-23 から，基礎下 部よりも基礎上部の方が間隙水圧比は大きく, 外力の変 化に対して負の間隙水圧が発生しや寸いことがわかる. 


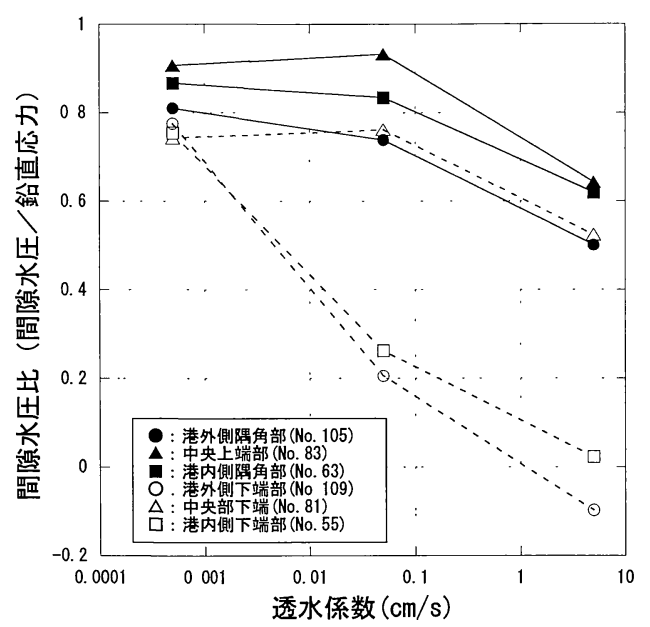

図-23 透水係数と間隙水圧比の関係

また，透水係数が小さい方が，負の間隙水圧が発生しや すいことがわかる.さらに，基礎下部の港外側と港内側 では透水係数の変化に対して間隙水圧比は比較的敏感に 変化し, 透水倸数が $k=1 \mathrm{~cm} / \mathrm{s}$ のオーダーで間隙水圧比は ゼロ以下になっている，ところが，基礎下部の中央部と 基礎上部では透水係数の増加に対して間隙水圧比はあま り変化しておらず，透水係数が $k=1 \mathrm{~cm} / \mathrm{s}$ のオーダーでも 間隙水圧比は 0.5 以上となっている. したがって, 基礎 内部になるほど非排水条件が保たれやすくなり，負の間 隙水圧が発生しやすくなっているといえる. 特に, 基礎 上部では透水係数が $k=0.05 \mathrm{~cm} / \mathrm{s}$ までは間隙水圧比は 0.7 以上になっている. サクション基礎が適用される地盤は 砂やシルト, 粘土地盤であり, 透水係数は $k=0.1 \mathrm{~cm} / \mathrm{s}$ 以 下と考えられる. ここでの計算は直径 $2 \mathrm{~m}$ の模型基礎を 対象にしているが，実際の防波堤基礎として適用した場 合には直径 $10 \mathrm{~m}$ 以上となり排水長は長くなる. このよう なことから，計算で作用させた波浪周期は $2.5 \mathrm{~s}$ と実海域 の波浪より短いが，実際には計算で対象としたものより 排水性は低下寸ると考えられる. したがって，数值計算 からの推定ではあるが，実際のサクション基礎では波浪 による水平力で引き抜き力が作用しても, 基礎上部の頂 盤付近では非排水条件が保たれて負の間隙水圧が発生し， 基礎が引き抜かれて破壊することは起こりにくいと考え られる. 現在のサクション基礎の設計では，基礎本体が 基礎内土を残して抜け出すモードでの破壊を検討するこ とになっているが，この際，隅角部などの基礎上部では 完全排水を仮定し負の間隙水圧の発生は全く考慮されて いない，したがって，現行設計法に負の間隙水圧の抵抗 を取り入れていく必要があると考える. また，基礎下端 においても透水係数が $k=0.001 \mathrm{~cm} / \mathrm{s}$ 以下では間隙水圧比 は 0.8 近くになっており, 引き抜き時に大きな負の間隙
水圧が発生する結果となっている.サクション基礎の設 計では基礎内土を含めた基礎全体の転倒モードによる破 壞を検討するが，この場合も負の間隙水圧の発生は無視 されており，透水係数が比較的低い場合には負の間隙水 圧の発生により転倒に対する抵抗があると考えられ，こ のような負の間隙水圧の抵抗を取り入れる必要があると いえる.

\section{6. まとめ}

サクション基礎を利用した防波堤に関して水理模型 実験および数值計算を行い以下のような結果を得た.

\section{実験から}

(1)設計波が作用するまでは残留変位はほとんど発生せず, 設計波を作用させても破壊にはいたらず，小さな残留沈 下が発生する程度であった。

(2)基礎が回転モードで抜け上がるときに負の間隙水圧が 発生していた.

(3)堤体に作用する波力が大きくなるほどサクション基礎 内に発生する負の間隙水圧は大きくなっていた.

(4)全応力が減少することに対して発生する負の間隙水圧 とせん断によるダイレイタンシーに起因した負の間隙水 圧の 2 種類の負の間隙水圧の発生を確認した.

数値計算から

(5)実験での基整壁が押し込まれるときの基礎下端での荷 重の集中を数值計算モデルは十分に再現できなかった. (6)数值計算は波浪載荷時の地盤の排水性，引き抜きに対 する負の間隙水圧の発生について実験結果を比較的良く 説明していた.

(7)数值計算からの推定ではあるが，水平荷重の作用によ る基礎の抜け上がりに対して, サクション基礎上部では 大きな負の間隙水圧の発生が期待できる. また，基礎下 部でも地盤の透水倸数が低い場合には負の間隙水圧の発 生が期待できる.

以上の(1)〜7)のような結果を得たが，既に提案されて いるサクション基礎構造物の設計法には, 外力に応じて 発生する負の間隙水圧の抵抗が取り込まれていない.こ こでの検討は負の間隙水圧発生の確認, 発生する負の間 隙水圧の特性や特徵を調べたもので, 基礎的研究にとど まっており，実務への応用にまでは至っていない，今後 は，水理実験などでさらに検討し，また，数值計算プロ グラムについても改良を行い，負の間隙水圧の発生を定 量化し設計に取り入れる必要があると考える.

本研究の一部は九州大学, 財団法人沿岸開発技術研究 センター, および民間会社 20 社から構成される共同研 究 ${ }^{17)}$ の成果の一部である. 
謝辞 : 研究の実施に際して北陸地方整備局のご協力をい ただいた，数値計算プログラムの使用にあたっては，港 湾空港技術研究所鈴木高二朗主任研究官, 韓国海洋研究 所朴佑善博士のご協力をいただいた．また，取りまとめ 過程において関西空港株式会社森川嘉之博士（元港湾空 港技術研究所主任研究官）のご協力をいただいた. 末筆 ながら各位に謝意を表します。

\section{参考文献}

1） 善功企, 山㠃浩之, 前田健一 : サクションによるケーソン 基礎の海底地盤中への沈設に関する事例解析，土木学会論 文集, No.603／III-44，pp.21-34,1997.

2）山嵪浩之: サクション基礎の開発について, 平成 12 年度港 湾技術研究所講演会, pp.17-38, 2000.

3）大島実 : 真空沈設工法による PC 管式防波堤，土木施工， 第3 巻, 第 5 号, pp.13-19, 1962.

4）高橋良正, 古池清一, 白石哲也, 足立一美 : サクション基 礎構造物の実証試験結果について, 海洋開発論文集, 第 18 巻, pp. 599-604, 2002.

5) 山㟝浩之, 森川嘉之, 小池二三勝, 出野 雅和, 矢沢 岳 : サクション基礎構造物の安定性に関する模型実験，港湾空 港技術研究所報告，第 24 巻，第 1 号, pp. 167-212， 2003.

6) 山嵪浩之, 森川嘉之, 小池二三勝, 矢沢岳 : 水平荷重を受 けるサクション基礎の安定性に関する模型実験, 海洋開発 論文集，第 19 巻，pp. 511-516， 2003.

7）国土交通省北陸地方整備局 : サクション基礎構造物設計・ 施工マニュアル (案)，国土交通省北陸地方整㣁局新潟港湾 空港技術調査事務所，pp. 27-41，2001.
8）沿岸開発技術研究センター: サクション基礎構造物技術マ ニュアル, pp. 26-38, 2003.

9）山㠃浩之，善功企，舘下徹和 : サクション基礎の引抜き抵 抗のメカニズムに関する研究, 第 39 回土質工学シンポジウ 厶, pp. 73-80, 1994.

10) 下迫健一郎, 藤原隆一, 中川将秀, 黒田豊和 : サクション 基礎防波堤の而波安定性に関する水理模型実験，港湾空港 技術研究所資料，pp. 7-9， No.1027， 2002.

11) 下迫健一郎, 藤原隆一, 中川将秀, 黒田豊和 : サクション 基礎を用いた防波堤の耐波安定性実験，海洋開発論文集， 第 18 巻, pp. 275-280, 2002.

12）高橋重雄, 山㠃浩之, 下迫健一郎, 姜閏求, 善功企, 高山 知司 : 大規模波動地盤水路の建設とその利用, 海洋開発論 文集，第 16 巻，pp. 421-426，2000.

13) 前出 8), pp. 16-41.

14）朴佑善, 高橋重雄, 鈴木高二朗, 姜閏求 : 波一地盤一構造 物の相互作用に関する有限要素解析, 海岸工学論文集, 第 43 巻, pp. 1036-1040, 1996.

15）例えば, 山口柏樹: 土質力学 (全改定), 技報堂, pp.99-101, 1984.

16) 沿岸開発技術研究センター : 埋立地の液状化対策ハンドブ ック (改訂版), pp. 66-69, 1997.

17）山嵪浩之, 善功企, 後藤克史 : サクション基礎を活用した 構造物に関する共同研究, 土と基礎, 第 50 巻, No.4, pp. 28-30, 2002 .

(2003.6. 30 受付)

\title{
EXPERIMENT ON WAVE RESPONSE OF SUCTION FOUNDATION USED FOR BREAKWATER AND ITS ANALYSIS BY NUMERICAL METHOD
}

\author{
Hiroyuki YAMAZAKI, Kenichiro SHIMOSAKO and Masahide NAKAGAWA
}

This paper describes the behaviours of suction foundations used for breakwaters during wave actions, mainly about pore water pressures and stresses in the foundation soil. The study has been conducted with the large hydro-geo flume which can generate waves of $3.5 \mathrm{~m}$ and with a two dimensional finite element program based on the elastic theory, which can estimate the behaviours of pore water pressures and stresses in the foundation soil as well as super structure's displacements under wave action. The study has revealed that negative pore water pressure generates inside the suction foundation during wave action and contributes to the resistance of the breakwater against the wave action. And also the mechanism of the generation of the negative pore water pressure under horizontal loads is discussed. 